4

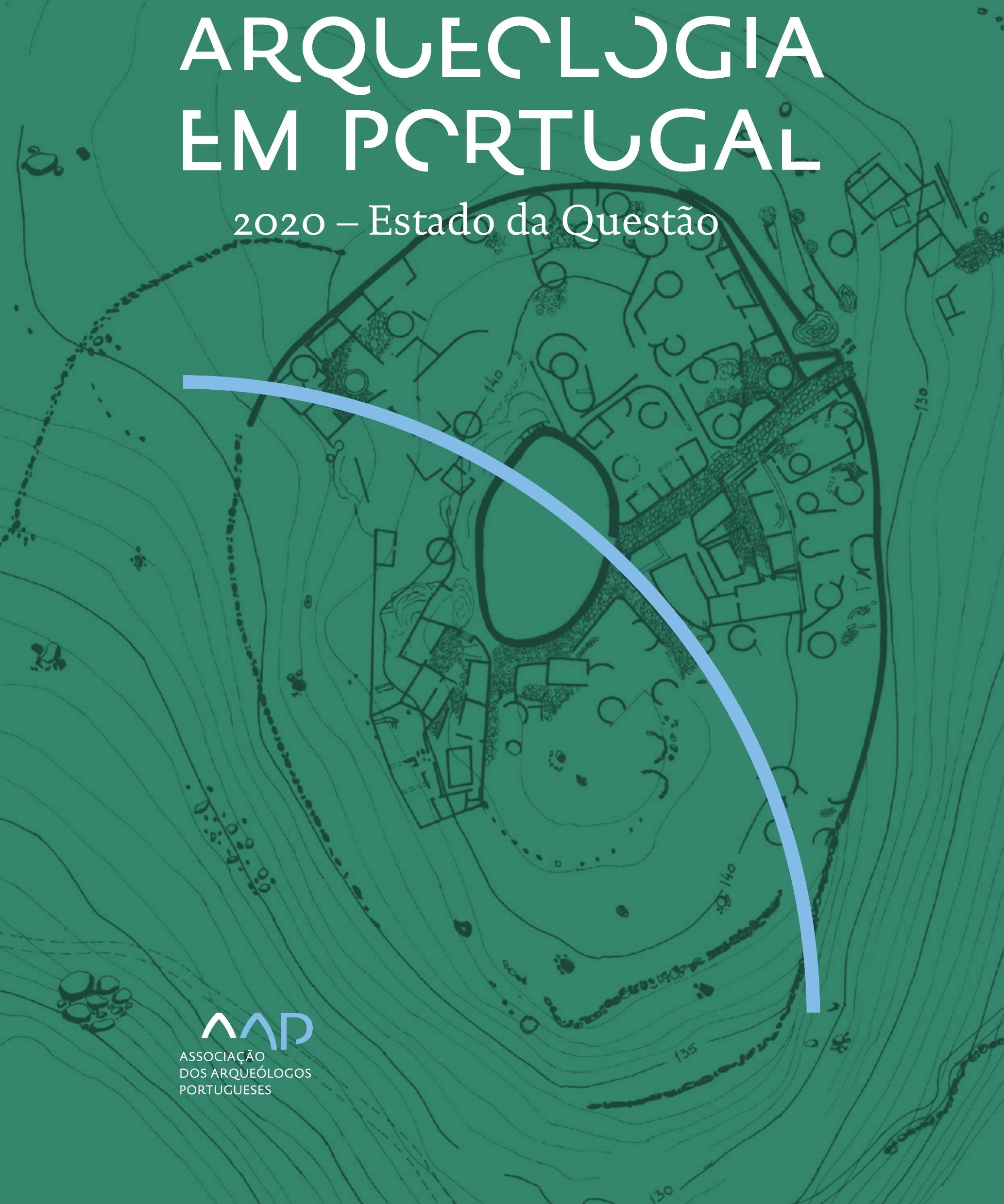


Coordenação editorial: José Morais Arnaud, César Neves e Andrea Martins Design gráfico: Flatland Design

AAP - ISBN: 978-972-9451-89-8

CITCEM - ISBN: 978-989-8970-25-1

Associação dos Arqueólogos Portugueses e CITCEM

Lisboa, 2020

O conteúdo dos artigos é da inteira responsabilidade dos autores. Sendo assim a Associação dos Arqueólogos Portugueses declina qualquer responsabilidade por eventuais equívocos ou questões de ordem ética e legal.

Desenho de capa:

Planta do castro de Monte Mozinho (Museu Municipal de Penafiel).

\section{$\hat{\wedge} \mathrm{P}$}

DOS ARQUEÓLOGOS PORTUGUESES

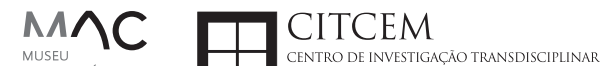
MUSEU
ARQUELLÓGICO
DO CARMO
U.PORTO

FLUP FACULDADE DE LETRAS
UNIVERSIDADE DO PORTO

Apoio

EC para a Ciência 


\section{Índice}

15 Prefácio

José Morais Arnaud

\section{Historiografia e Teoria}

17 Território, comunidade, memória e emoção: a contribuição da história da arqueologia (algumas primeiras e breves reflexões)

Ana Cristina Martins

25 Como descolonizar a arqueologia portuguesa?

Rui Gomes Coelho

41 Arqueologia e Modernidade: uma revisitação pessoal e breve de alguns aspetos da obra homónima de Julian Thomas de 2004

Vítor Oliveira Jorge

57 Dados para a História das Mulheres na Arqueologia portuguesa, dos finais do século XIX aos inícios do século XX: números, nomes e tabelas

Filipa Dimas / Mariana Diniz

73 Retractos da arqueologia portuguesa na imprensa: (in)visibilidades no feminino

Catarina Costeira / Elsa Luís

85 Arqueologia e Arqueólogos no Norte de Portugal Jacinta Bugalhão

101 Vieira Guimarães (1864-1939) e a arqueologia em Tomar: uma abordagem sobre o território e as gentes

João Amendoeira Peixoto / Ana Cristina Martins

115 Os memoráveis? A arqueologia algarvia na imprensa nacional e regional na presente centúria (2001-2019): características, visões do(s) passado(s) e a arqueologia

enquanto marca

Frederico Agosto / João Silva

129 A Evolução da Arqueologia Urbana e a Valorização Patrimonial no Barlavento Algarvio: Os casos de Portimão e Silves

Artur Mateus / Diogo Varandas / Rafael Boavida

\section{Gestão, Valorização e Salvaguarda do Património}

145 O Caderno Reivindicativo e as condições de trabalho em Arqueologia Miguel Rocha / Liliana Matias Carvalho / Regis Barbosa / Mauro Correia / Sara Simões / Jacinta Bugalhão / Sara Brito / Liliana Veríssimo Carvalho / Richard Peace / Pedro Peça / Cézer Santos

155 Os Estudos de Impacte Patrimonial como elemento para uma estratégia sustentável de minimização de impactes no âmbito de reconversões agrícolas Tiago do Pereiro

165 Salvaguarda de Património arqueológico em operações florestais: gestão e sensibilização Filipa Bragança / Gertrudes Zambujo / Sandra Lourenço / Belém Paiva / Carlos Banha / Frederico Tatá Regala / Helena Moura / Jacinta Bugalhão / João Marques / José Correia / Pedro Faria / Samuel Melro

179 Os valores do Património: uma investigação sobre os Sítios Pré-históricos de Arte Rupestre do Vale do Rio Côa e de Siega Verde José Paulo Francisco 
189 Conjugando recursos arqueológicos e naturais para potenciar as visitas ao Geoparque Litoral de Viana do Castelo (Noroeste de Portugal)

Hugo A. Sampaio / Ana M.S. Bettencourt / Susana Marinho / Ricardo Carvalhido

203 Áreas de Potencial Arqueológico na Região do Médio Tejo: Modelo Espacial Preditivo Rita Ferreira Anastácio / Ana Filipa Martins / Luiz Oosterbeek

223 Património Arqueológico e Gestão Territorial: O contributo da Arqueologia para a revisão do PDM de Avis

Ana Cristina Ribeiro

237 A coleção arqueológica do extinto Museu Municipal do Porto - Origens, Percursos e Estudos

Sónia Couto

251 Valpaços - uma nova carta arqueológica

Pedro Pereira / Maria de Fátima Casares Machado

263 Arqueologia na Cidade de Peniche

Adriano Constantino / Luís Rendeiro

273 Arqueologia Urbana: a cidade de Lagos como caso de Estudo Cátia Neto

285 Estratégias de promoção do património cultural subaquático nos Açores. O caso da ilha do Faial

José Luís Neto / José Bettencourt / Luís Borges / Pedro Parreira

297 Carta Arqueológica da Cidade Velha: Uma primeira abordagem

Jaylson Monteiro / Nireide Tavares / Sara da Veiga / Claudino Ramos / Edson Brito /

Carlos Carvalho / Francisco Moreira / Adalberto Tavares

311 Antropologia Virtual: novas metodologias para a análise morfológica e funcional Ricardo Miguel Godinho / Célia Gonçalves

\section{Didáctica da Arqueologia}

327 Como os projetos de Arqueologia podem contribuir para uma comunidade culturalmente mais consciente Alexandra Figueiredo / Claúdio Monteiro / Adolfo Silveira / Ricardo Lopes

337 Educação Patrimonial - Um cidadão esclarecido é um cidadão ativo! Ana Paula Almeida

351 A aproximação da Arqueologia à sala de aula: um caso de estudo no $3^{\circ}$ ciclo do Ensino Básico Luís Serrão Gil

363 Arqueologia 3.o - Pensar e comunicar a Arqueologia para um futuro sustentável Mónica Rolo

377 “Conversa de Arqueólogos" - Divulgar a Arqueologia em tempos de Pandemia Diogo Teixeira Dias

389 Escola Profissional de Arqueologia: desafios e oportunidades Susana Nunes / Dulcineia Pinto / Júlia Silva / Ana Mascarenhas

399 Os Museus de Arqueologia e os Jovens: a oferta educativa para o público adolescente Beatriz Correia Barata / Leonor Medeiros

411 O museu universitário como mediador entre a ciência e a sociedade: o exemplo da secção de arqueologia no Museu de História Natural e da Ciência da Universidade do Porto (MHNC-UP)

Rita Gaspar 
421 Museu de Lanifícios: Real Fábrica de Panos. Atividades no âmbito da Arqueologia Beatriz Correia Barata / Rita Salvado

427 Arqueologia Pública e o caso da localidade da Mata (Torres Novas) Cláudia Manso / Ana Rita Ferreira / Cristiana Ferreira / Vanessa Cardoso Antunes

431 Do sítio arqueológico ao museu: um percurso (também) didático Lídia Fernandes

447 Estão todos convidados para a Festa! E para dançar também... O projecto do Serviço Educativo do Museu Arqueológico do Carmo na $5^{\underline{a}}$ Edição da Festa da Arqueologia Rita Pires dos Santos

459 O “Clã de Carenque”, um projeto didático de arqueologia Eduardo Gonzalez Rocha

469 Mediação cultural: peixe que puxa carroça nas Ruínas Romanas de Troia Inês Vaz Pinto / Ana Patrícia Magalhães / Patrícia Brum / Filipa Santos

481 Didática Arqueológica, experiências do Projeto Mértola Vila Museu Maria de Fátima Palma / Clara Rodrigues / Susana Gómez / Lígia Rafael

\section{Arte Rupestre}

497 Os inventários de arte rupestre em Portugal Mila Simões de Abreu

513 O projeto FIRST-ART - conservação, documentação e gestão das primeiras manifestações de arte rupestre no Sudoeste da Península Ibérica: as grutas do Escoural e Maltravieso Sara Garcês / Hipólito Collado / José Julio García Arranz / Luiz Oosterbeek / António Carlos Silva / Pierluigi Rosina / Hugo Gomes / Anabela Borralheiro Pereira / George Nash / Esmeralda Gomes / Nelson Almeida / Carlos Carpetudo

523 Trabalhos de documentação de arte paleolítica realizados no âmbito do projeto PalæoCôa André Tomás Santos / António Fernando Barbosa / Luís Luís / Marcelo Silvestre / Thierry Aubry

537 Imagens fantasmagóricas, silhuetas elusivas: as figuras humanas na arte do Paleolítico Superior da região do Côa Mário Reis

$55^{1}$ Os motivos zoomórficos representados nas placas de tear de Vila Nova de São Pedro (Azambuja, Portugal) Andrea Martins / César Neves / José M. Arnaud / Mariana Diniz

571 Arte Rupestre do Monte de Góios (Lanhelas, Caminha). Síntese dos resultados dos trabalhos efectuados em 2007-2009 Mário Varela Gomes

599 Gravuras rupestres de barquiformes no Monte de S. Romão, Guimarães, Noroeste de Portugal Daniela Cardoso

613 Círculos segmentados gravados na Bacia do Rio Lima (Noroeste de Portugal): contributos para o seu estudo Diogo Marinho / Ana M.S. Bettencourt / Hugo Aluai Sampaio

631 Equídeos gravados no curso inferior do Rio Mouro, Monção (NW Portugal). Análise preliminar Coutinho, L.M. / Bettencourt, A.M.S / Sampaio, Hugo A.S

645 Paletas na Arte Rupestre do Noroeste de Portugal. Inventário preliminar Bruna Sousa Afonso / Ana M. S. Bettencourt / Hugo A. Sampaio 


\section{Pré-História}

661 O projeto Miño/Minho: balanço de quatro anos de trabalhos arqueológicos Sérgio Monteiro-Rodrigues / João Pedro Cunha-Ribeiro / Eduardo Méndez-Quintas / Carlos Ferreira / Pedro Xavier / José Meireles / Alberto Gomes / Manuel Santonja / Alfredo Pérez-González

677 A ocupação paleolítica da margem esquerda do Baixo Minho: a indústria lítica do sítio de Pedreiras 2 (Monção, Portugal) e a sua integração no contexto regional Carlos Ferreira / João Pedro Cunha-Ribeiro / Sérgio Monteiro-Rodrigues / Eduardo Méndez-Quintas / Pedro Xavier / José Meireles / Alberto Gomes / Manuel Santonja / Alfredo Pérez-González

693 O sítio acheulense do Plistocénico médio da Gruta da Aroeira Joan Daura / Montserrat Sanz / Filipa Rodrigues / Pedro Souto / João Zilhão

703 As sociedades neandertais no Barlavento algarvio: modelos preditivos com recurso aos SIG

Daniela Maio

715 A utilização de quartzo durante o Paleolítico Superior no território dos vales dos rios Vouga e Côa

Cristina Gameiro / Thierry Aubry / Bárbara Costa / Sérgio Gomes / Luís Luís / Carmen Manzano / André Tomás Santos

733 Uma perspetiva diacrónica da ocupação do concheiro do Cabeço da Amoreira (Muge, Portugal) a partir da tecnologia lítica Joana Belmiro / João Cascalheira / Célia Gonçalves

745 Novos dados sobre a Pré-história Antiga no concelho de Palmela. A intervenção arqueológica no sítio do Poceirão I

Michelle Teixeira Santos

757 Problemas em torno de Datas Absolutas Pré-Históricas no Norte do Alentejo Jorge de Oliveira

771 Povoamento pré-histórico nas áreas montanhosas do NO de Portugal: o Abrigo 1 de Vale de Cerdeira Pedro Xavier / José Meireles / Carlos Alves

783 Apreciação do povoamento do Neolítico Inicial na Baixa Bacia do Douro. A Lavra I (Serra da Aboboreira) como caso de estudo Maria de Jesus Sanches

797 O Processo de Neolitização na Plataforma do Mondego: os dados do Sector C do Outeiro dos Castelos de Beijós (Carregal do Sal)

João Carlos de Senna-Martinez / José Manuel Quintã Ventura / Andreia Carvalho / Cíntia Maurício

823 Novos trabalhos na Lapa da Bugalheira (Almonda, Torres Novas) Filipa Rodrigues / Pedro Souto / Artur Ferreira / Alexandre Varanda / Luís Gomes / Helena Gomes / João Zilhão

837 A pedra polida e afeiçoada do sítio do Neolítico médio da Moita do Ourives (Benavente, Portugal)

César Neves

857 Casal do Outeiro (Encarnação, Mafra): novos contributos para o conhecimento do povoamento do Neolítico final na Península de Lisboa.

Cátia Delicado / Carlos Maneira e Costa / Marta Miranda / Ana Catarina Sousa

873 Stresse infantil, morbilidade e mortalidade no sítio arqueológico do Neolítico Final/ Calcolítico ( $4^{\circ}$ e $3^{\circ}$ milénio a.C.) do Monte do Carrascal 2 (Ferreira do Alentejo, Beja) Liliana Matias de Carvalho / Sofia N. Wasterlain 
885 Come together: O Conjunto Megalítico das Motas (Monção, Viana do Castelo) e as expressões Campaniformes do Alto Minho Ana Catarina Basílio / Rui Ramos

899 Trabalhos arqueológicos no sítio Calcolítico da Pedreira do Poio Carla Magalhães / João Muralha / Mário Reis / António Batarda Fernandes

913 O sítio arqueológico de Castanheiro do Vento. Da arquitectura do sítio à arquitectura de um território João Muralha Cardoso

925 Estudo zooarqueológico das faunas do Calcolítico final de Vila Nova de São Pedro (Azambuja, Portugal): Campanhas de 2017 e 2018 Cleia Detry / Ana Catarina Francisco / Mariana Diniz / Andrea Martins / César Neves / José Morais Arnaud

943 As faunas depositadas no Museu Arqueológico do Carmo provenientes de Vila Nova de São Pedro (Azambuja): as campanhas de 1937 a 1967 Ana Catarina Francisco / Cleia Detry / César Neves / Andrea Martins / Mariana Diniz / José Morais Arnaud

959 Análise funcional de material lítico em sílex do castro de Vila Nova de S. Pedro (Azambuja, Portugal): uma primeira abordagem Rafael Lima

971 O recinto da Folha do Ouro 1 (Serpa) no contexto dos recintos de fossos calcolíticos alentejanos

António Carlos Valera / Tiago do Pereiro / Pedro Valério / António M. Monge Soares

\section{Proto-História}

987 Produção de sal marinho na Idade do Bronze do noroeste Português. Alguns dados para uma reflexão

Ana M. S. Bettencourt / Sara Luz / Nuno Oliveira / Pedro P. Simões / Maria Isabel C. Alves / Emílio Abad-Vidal

1001 A estátua-menir do Pedrão ou de São Bartolomeu do Mar (Esposende, noroeste de Portugal) no contexto arqueológico da fachada costeira de entre os rios Neiva e Cávado Ana M. S. Bettencourt / Manuel Santos-Estévez / Pedro Pimenta Simões / Luís Gonçalves

1015 O Castro do Muro (Vandoma/Baltar, Paredes) - notas para uma biografia de ocupação da Idade do Bronze à Idade Média

Maria Antónia D. Silva / Ana M. S. Bettencourt / António Manuel S. P. Silva / Natália Félix

1031 Do Bronze Final à Idade Média - continuidades e hiatos na ocupação de Povoados em Oliveira de Azeméis João Tiago Tavares / Adriaan de Man

1041 As faunas do final da Idade do Bronze no Sul de Portugal: leituras desde o Outeiro do Circo (Beja)

Nelson J. Almeida / Íris Dias / Cleia Detry / Eduardo Porfírio / Miguel Serra

1055 A Espada do Monte das Oliveiras (Serpa) - uma arma do Bronze Pleno do Sudoeste Rui M. G. Monge Soares / Pedro Valério / Mariana Nabais / António M. Monge Soares

1065 São Julião da Branca (Albergaria-a-Velha) - Investigação e valorização de um povoado do Bronze Final

António Manuel S. P. Silva / Paulo A. P. Lemos / Sara Almeida e Silva / Edite Martins de Sá

1083 Do castro de S. João ao Mosteiro de Santa Clara: notícia de uma intervenção arqueológica, em Vila do Conde Rui Pinheiro 
1095 O castro de Ovil (Espinho), um quarto de século de investigação - resultados e questões em aberto

Jorge Fernando Salvador / António Manuel S. P. Silva

1111 O Castro de Salreu (Estarreja), um povoado proto-histórico no litoral do Entre Douro e Vouga

Sara Almeida e Silva / António Manuel S. P. Silva / Paulo A. P. Lemos / Edite Martins de Sá

1127 Castro de Nossa Senhora das Necessidades (Sernancelhe): uma primeira análise artefactual Telma Susana O. Ribeiro

${ }_{1141}$ A cividade de Bagunte. O estado atual da investigação Pedro Brochado de Almeida

1153 Zoomorfos na cerâmica da Idade do Ferro no NW Peninsular: inventário, cronologias e significado Nuno Oliveira / Cristina Seoane

1163 Vasos gregos em Portugal: diferentes maneiras de contar a história do intercâmbio cultural na Idade do Ferro

Daniela Ferreira

1175 Os exotica da necrópole da Idade do Ferro do Olival do Senhor dos Mártires (Alcácer do Sal) no seu contexto regional

Francisco B. Gomes

\section{Antiguidade Clássica e Tardia}

1191 O uso de madeira como combustível no sítio da Quinta de Crestelos (Baixo Sabor): da Idade do Ferro à Romanização Filipe Vaz / João Tereso / Sérgio Simões Pereira / José Sastre / Javier Larrazabal Galarza / Susana Cosme / José António Pereira / Israel Espi

1207 Cultivos de Época Romana no Baixo Sabor: continuidade em tempos de mudança? João Pedro Tereso / Sérgio Simões Pereira / Filipe Santos / Luís Seabra / Filipe Vaz

1221 A casa romana na Hispânia: aplicação dos modelos itálicos nas províncias ibéricas Fernanda Magalhães / Diego Machado / Manuela Martins

1235 As pinturas murais romanas da Rua General Sousa Machado, n. ${ }^{5}$ 1, Chaves José Carvalho

1243 Trás do Castelo (Vale de Mir, Pegarinhos, Alijó) - Uma exploração agrícola romana do Douro

Tony Silvino / Pedro Pereira

1255 A sequência de ocupação no quadrante sudeste de Bracara Augusta: as transformações de uma unidade doméstica Lara Fernandes / Manuela Martins

1263 Os Mosaicos com decoração geométrica e geométrico-vegetalista dos sítios arqueológicos da área do Conuentus Bracaraugustanus. Novas abordagens quanto à conservação, restauro, decoração e datação Maria de Fátima Abraços / Licínia Wrench

1277 “Casa Romana” do Castro de São Domingos (Cristelos, Lousada): Escavação, Estudo e Musealização Paulo André de P. Lemos

1291 A arqueobotânica no Castro de Guifões (Matosinhos, Noroeste de Portugal): O primeiro estudo carpológico

Luís Seabra / Andreia Arezes / Catarina Magalhães / José Varela / João Pedro Tereso 
1305 Um Horreum Augustano na Foz do Douro (Monte do Castelo de Gaia, Vila Nova de Gaia) Rui Ramos

1311 Ponderais romanos na Lusitânia: padrões, formas, materiais e contextos de utilização Diego Barrios Rodríguez

1323 Um almofariz centro-itálico na foz do Mondego

Marco Penajoia

1335 Estruturas romanas de Carnide - Lisboa Luísa Batalha / Mário Monteiro / Guilherme Cardoso

1347 O contexto funerário do sector da "necrópole NO" da Rua das Portas de S. Antão (Lisboa): o espaço, os artefactos, os indivíduos e a sua interconectividade na interpretação do passado Sílvia Loja, José Carlos Quaresma, Nelson Cabaço, Marina Lourenço, Sílvia Casimiro, Rodrigo Banha da Silva, Francisca Alves-Cardoso

${ }_{1361}$ Povoamento em época Romana na Amadora - resultados de um projeto pluridisciplinar Gisela Encarnação / Vanessa Dias

1371 A Arquitectura Residencial em Mirobriga (Santiago do Cacém): contributo a partir de um estudo de caso Filipe Sousa / Catarina Felício

${ }_{1385}$ O fim do ciclo. Saneamento e gestão de resíduos nos edifícios termais de Mirobriga (Santiago do Cacém)

Catarina Felício / Filipe Sousa

1399 Balsa, Topografia e Urbanismo de uma Cidade Portuária Vítor Silva Dias / João Pedro Bernardes / Celso Candeias / Cristina Tété Garcia

1413 No Largo das Mouras Velhas em Faro (2017): novas evidências da necrópole norte de Ossonoba e da sua ocupação medieval Ricardo Costeira da Silva / Paulo Botelho / Fernando Santos / Liliana Nunes

1429 Instrumentos de pesca recuperados numa fábrica de salga em Ossonoba (Faro) Inês Rasteiro / Ricardo Costeira da Silva / Paulo Botelho

1439 A Necrópole Romana do Eirô, Duas Igrejas (Penafiel): intervenção arqueológica de 2016 Laura Sousa / Teresa Soeiro

1457 Ritual, descarte ou afetividade? A presença de Canis lupus familiaris na Necrópole Noroeste de Olisipo (Lisboa)

Beatriz Calapez Santos / Sofia Simões Pereira / Rodrigo Banha da Silva / Sílvia Casimiro / Cleia Detry / Francisca Alves Cardoso

1467 Dinâmicas económicas em Bracara na Antiguidade Tardia Diego Machado / Manuela Martins / Fernanda Magalhães / Natália Botica

1479 Cerâmicas e Vidros da Antiguidade Tardia do Edifício sob a Igreja do Bom Jesus (Vila Nova de Gaia) Joaquim Filipe Ramos

1493 Novos contributos para a topografia histórica de Mértola no período romano e na Antiguidade Tardia Virgílio Lopes

\section{8. Época Medieval}

1511 Cerâmicas islâmicas no Garb setentrional "português": algumas evidências e incógnitas Constança dos Santos / Helena Catarino / Susana Gómez / Maria José Gonçalves / Isabel Inácio / Gonçalo Lopes / Jacinta Bugalhão / Sandra Cavaco / Jaquelina Covaneiro / Isabel Cristina Fernandes / Ana Sofia Gomes 
1525 Contributo para o conhecimento da cosmética islâmica, em Silves, durante a Idade Média Rosa Varela Gomes

1537 Yábura e o seu território - uma análise histórico-arqueológica de Évora entre os séculos VIII-XII José Rui Santos

1547 A encosta sul do Castelo de Palmela - resultados preliminares da escavação arqueológica Luís Filipe Pereira / Michelle Teixeira Santos

1559 A igreja de São Lourenço (Mouraria, Lisboa): um conjunto de silos e de cerâmica medieval islâmica

Andreia Filipa Moreira Rodrigues

1571 O registo material de movimentações populacionais no Médio Tejo, durante os séculos XII-XIII. Dois casos de "sunken featured buildings", nos concelhos de Cartaxo e Torres Novas Marco Liberato / Helena Santos / Nuno Santos

1585 O nordeste transmontano nos alvores da Idade média. Notas para reflexão Ana Maria da Costa Oliveira

1601 Sepulturas escavadas na rocha do Norte de Portugal e do Vale do Douro: primeiros resultados do Projecto SER-NPVD

Mário Jorge Barroca / César Guedes / Andreia Arezes / Ana Maria Oliveira

1619 "Portucalem Castrum Novum" entre o Mediterrâneo e o Atlântico: o estudo dos materiais cerâmicos alto-medievais do arqueossítio da rua de D. Hugo, nํ. 5 (Porto) João Luís Veloso

1627 A Alta Idade Média na fronteira de Lafões: notas preliminares sobre a Arqueologia no Concelho de Vouzela

Manuel Luís Real / Catarina Tente

1641 Um conjunto cerâmico medieval fora de portas: um breve testemunho aveirense Susana Temudo

${ }_{1651}$ Os Lóios do Porto: uma perspetiva integrada no panorama funerário da Baixa Idade Média à Época Moderna em meios urbanos em Portugal

Ana Lema Seabra

1659 O Caminho Português Interior de Santiago como eixo viário na Idade Média Pedro Azevedo

1665 Morfologia Urbana: Um exercício em torno do Castelo de Ourém André Donas-Botto / Jaqueline Pereira

1677 Intervenção arqueológica na Rua Marquês de Pombal/Largo do Espírito Santo (Bucelas, Loures)

Florbela Estêvão / Nathalie Antunes-Ferreira / Dário Ramos Neves / Inês Lisboa

1691 O Cemitério Medieval do Poço do Borratém e a espacialidade funerária na cidade de Lisboa Inês Belém / Vanessa Filipe / Vasco Noronha Vieira / Sónia Ferro / Rodrigo Banha da Silva

1705 Um Espaço Funerário Conventual do séc. XV em Lisboa: o caso do Convento de São Domingos da Cidade Sérgio Pedroso / Sílvia Casimiro / Rodrigo Banha da Silva / Francisca Alves Cardoso

\section{9. Época Moderna e Contemporânea}

1721 Arqueologia Moderna em Portugal: algumas reflexões críticas em torno da quantificação de conjuntos cerâmicos e suas inferências históricas e antropológicas Rodrigo Banha da Silva / André Bargão / Sara da Cruz Ferreira

1733 Faianças de dois contextos entre os finais do século XVI e XVIII do Palácio dos Condes de Penafiel, Lisboa

Martim Lopes / Tomás Mesquita 
1747 Um perfil de consumo do século XVIII na foz do Tejo: O caso do Mercado da Ribeira, Lisboa Sara da Cruz Ferreira / Rodrigo Banha da Silva / André Bargão

1761 Os Cachimbos dos Séculos XVII e XVIII do Palácio Mesquitela e Convento dos Inglesinhos (Lisboa)

Inês Simão / Marina Pinto / João Pimenta / Sara da Cruz Ferreira / André Bargão / Rodrigo Banha da Silva

1775 "Tomar os fumos da erua que chamão em Portugal erua sancta». Estudo de Cachimbos provenientes da Rua do Terreiro do Trigo, Lisboa

Miguel Martins de Sousa / José Pedro Henriques / Vanessa Galiza Filipe

1787 Cachimbos de Barro Caulínitico da Sé da Cidade Velha (República de Cabo Verde)

Rodrigo Banha da Silva / João Pimenta / Clementino Amaro

1801 Algumas considerações sobre espólio não cerâmico recuperado no Largo de Jesus (Lisboa) Carlos Boavida

1815 Adereços de vidro, dos séculos XVI-XVIII, procedentes do antigo Convento de Santana de Lisboa (anéis, braceletes e contas)

Joana Gonçalves / Rosa Varela Gomes / Mário Varela Gomes

1837 Da ostentação, luxo e poder à simplicidade do uso quotidiano: arqueologia e simbologia de joias e adornos da Idade Moderna Portuguesa Jéssica Iglésias

1849 Os amuletos em Portugal - dos objetos às superstições: o coral vermelho Alexandra Vieira

1865 Cerâmicas de Vila Franca de Xira nos séculos XV e XVI Eva Pires

1879 «Não passa por teu o que me pertence». Marcas de individualização associadas a faianças do Convento de Nossa Senhora de Aracoeli, Alcácer do Sal Catarina Parreira / Íris Fragoso / Miguel Martins de Sousa

1891 Cerâmica de Leiria: alguns focos de produção

Jaqueline Pereira / André Donas-Botto

1901 Os Fornos na Rua da Biquinha, em Óbidos Hugo Silva / Filipe Oliveira

1909 A casa de Pêro Fernandes, contador dos contos de D. Manuel I: o sítio arqueológico da Silha do Alferes, Seixal (século XVI) Mariana Nunes Ferreira

1921 O Alto da Vigia (Sintra) e a vigilância e defesa da costa Alexandre Gonçalves / Sandra Santos

1937 O contexto da torre sineira da Igreja de Santa Maria de Loures Paulo Calaveira / Martim Lopes

1949 A Necrópole do Hospital Militar do Castelo de São Jorge e as práticas funerárias na Lisboa de Época Moderna Susana Henriques / Liliana Matias de Carvalho / Ana Amarante / Sofia N. Wasterlain

1963 SAND - Sarilhos Grandes Entre dois Mundos: o adro da Igreja e a Paleobiologia dos ossos humanos recuperados

Paula Alves Pereira / Roger Lee Jesus / Bruno M. Magalhães

1975 Expansão urbana da vila de Cascais no século XVII e XVIII: a intervenção arqueológica na Rua da Vitória no 15 a 17

Tiago Pereira / Vanessa Filipe

1987 Novos dados para o conhecimento do Urbanismo de Faro em época Moderna Ana Rosa 
1995 Um exemplo de Arqueologia Urbana em Alcoutim: o Antigo Edifício dos CTT Marco Fernandes / Marta Dias / Alexandra Gradim / Virgílio Lopes / Susana Gómez Martínez

2007 Palácio dos Ferrazes (Rua das Flores/Rua da Vitória, Porto): a cocheira de Domingos Oliveira Maia

Francisco Raimundo

2021 As muitas vidas de um edifício urbano: História, Arqueologia e Antropologia no antigo Recreatório Paroquial de Penafiel Helena Bernardo / Jorge Sampaio / Marta Borges

2035 O convento de Nossa Senhora da Esperança de Ponta Delgada: o contributo da arqueologia para o conhecimento de um monumento identitário João Gonçalves Araújo / N’Zinga Oliveira

2047 Arqueologia na ilha do Corvo... em busca da capela de Nossa Senhora do Rosário Tânia Manuel Casimiro / José Luís Neto / Luís Borges / Pedro Parreira

2059 Perdidos à vista da Costa. Trabalhos arqueológicos subaquáticos na Barra do Tejo Jorge Freire / José Bettencourt / Augusto Salgado

2071 Arqueologia marítima em Cabo Verde: enquadramento e primeiros resultados do projecto CONCHA

José Bettencourt / Adilson Dias / Carlos Lima / Christelle Chouzenoux / Cristóvão Fonseca / Dúnia Pereira / Gonçalo Lopes / Inês Coelho / Jaylson Monteiro / José Lima / Maria Eugénia Alves / Patrícia Carvalho / Tiago Silva

2085 Trabalhos arqueológicos na Cidade Velha (Ribeira Grande de Santiago, Cabo Verde): reflexões sobre um projecto de investigação e divulgação patrimonial André Teixeira / Jaylson Monteiro / Mariana Mateus / Nireide Tavares / Cristovão Fonseca / Gonçalo C. Lopes / Joana Bento Torres / Dúnia Pereira / André Bargão / Aurélie Mayer / Bruno Zélie / Carlos Lima / Christelle Chouzenoux / Inês Henriques / Inês Pinto Coelho / José Lima / Patrícia Carvalho / Tiago Silva

2103 A antiga fortificação de Quelba / Khor Kalba (E.A.U.). Resultados de quatro campanhas de escavações, problemáticas e perspectivas futuras Rui Carita / Rosa Varela Gomes / Mário Varela Gomes / Kamyar Kamyad

2123 Colónias para homens novos: arqueologia da colonização agrária fascista no noroeste ibérico Xurxo Ayán Vila / José Mạ . Señorán Martín 


\title{
CASAL DO OUTEIRO (ENCARNAÇÃO, MAFRA): NOVOS CONTRIBUTOS PARA O CONHECIMENTO DO POVOAMENTO DO NEOLÍTICO FINAL NA PENÍNSULA DE LISBOA
}

\author{
Cátia Delicado $^{1}$, Carlos Maneira e Costa ${ }^{2}$, Marta Miranda $^{3}$, Ana Catarina Sousa ${ }^{1}$
}

\begin{abstract}
RESUMO
O sítio do Casal do Outeiro (Encarnação, Mafra), foi identificado em 2020 no âmbito de acompanhamento de uma empreitada. Situa-se numa encosta suave, de solos arenosos e a escassos metros de uma linha de água subsidiária do Rio Safarujo. A evidência artefactual parece indicar a presença um núcleo habitacional neolítico, possivelmente da segunda metade do $4^{\underline{0}}$ milénio, incluindo evidências de debitagem local em sílex, pedra polida e cerâmica manual, incluindo um fragmento de bordo denteado. As prospecções realizadas permitiram identificar possíveis ocorrências associadas ao Casal do Outeiro como grutas e cavidades sob rocha com materiais coevos. Discute-se este sítio face ao padrão de povoamento neolítico da Península de Lisboa, concentrado na parte mais meridional. Palavras-chave: Estremadura, Povoamento, Neolítico Final.
\end{abstract}

\begin{abstract}
Casal do Outeiro site (Encarnação, Mafra) was identified in 2020. It is located on a gentle slope, with sandy soils, a few meters from a water line subsidiary of the Safarujo River. The artefactual evidence seems to indicate the presence of a small neolithic settlement possibly from the second half of the $4^{\text {th }}$ millenium, including evidence of local flint debitage, polished stone and manual ceramics, including a fragment of a denticulated rim. The surveys carried out allowed to identify other sites associated with Casal do Outeiro as caves and rockshelters with coeval materials. This site is analysed regarding the neolithic patterns settlements of the Lisbon Peninsular, mostly located in the southern part.
\end{abstract}

Keywords: Estremadura, Settlement, Late Neolithic.

\section{INTRODUÇÃO}

O sítio arqueológico do Casal do Outeiro foi identificado no início de 2020 no decorrer trabalhos de acompanhamento de uma empreitada realizada no concelho de Mafra sob direção de dois dos signatários (CD, CC). Foram também detectados outros sítios inéditos com materiais de cronologias pré-históricos em posição relativamente próxima do Casal do Outeiro aqui também apresentados.
Estas ocorrências parecem indicar a existência de um núcleo de povoamento pré-histórico localizado no Norte do concelho de Mafra, na área vestibular da Ribeira do Safarujo, eventualmente relacionado com as dinâmicas de povoamento da bacia do Sizandro, em Torres Vedras.

Considerando as dificuldades de prospeção na Estremadura (Sousa, 2009) e do reduzido número de povoados abertos de cronologia neolítica identificados, entendemos ser pertinente a publicação

\footnotetext{
1. Centro de Arqueologia da Universidade de Lisboa - UNIARQ. Faculdade de Letras da Universidade de Lisboa.

2. Amphora Arqueologia, Lda.

3. Câmara Municipal de Mafra.
} 
preliminar destes vestígios, ainda que se admita o alcance limitado de uma análise efectuada exclusivamente através de dados de prospecção.

\section{ENQUADRAMENTO}

O sítio do Casal do Outeiro encontra-se localizado na extremidade Norte do concelho de Mafra, na freguesia da Encarnação, próximo dos limites fronteiriços com Torres Vedras, freguesia de São Pedro da Cadeira (Torres Vedras), apresentando as coordenadas WGS84 $39^{\circ}$ 2'41.78” N/ 9 21'29.36”'W, com $33 \mathrm{~m}$ de altitude. (Figura 1 )

Os achados foram detectados numa encosta de inclinação suave de terrenos arenosos sobranceiros ao Rio Pequeno, afluente da Ribeira da Carregueira, subsidiária do Rio Safarujo. O local de implantação situa-se geologicamente na transição das camadas do Portlandiano para uma área de drenagem de formações aluvionares entre o rio Sizandro e o rio Safarujo.

Actualmente o sítio localiza-se a cerca de $5 \mathrm{~km}$ do oceano e a $4 \mathrm{~km}$ do Rio Safarujo, sendo provável que o Rio Safarujo no óptimo climático do Atlântico tivesse um caudal bastante maior, a avaliar pelos estudos efectuados para a evolução da linha de costa no Holénico (Dias, 1978; Daveau, 1980) como foi documentado no vale do Sizandro (Hoffmann, 1990; Hoffmann e Schulz, 1995; Dambeck et al, 2015) e para o Alcabrichel (Aleixo et al, 2014) (Figura 2).

Certamente que os recursos aquáticos teriam um papel importante na economia local, sendo muito próxima a sua captação quer da costa atlântica quer das margens da bacia do Safarujo. Os solos apresentam também aptidão agrícola, como é patente no actual uso do solo. Nos terraços do Sizandro o sílex estaria disponível (Jordão e Pimentel, 2019) sendo ainda necessário proceder ao estudo de eventuais áreas de captação mais próxima, como a mina detectada em Casal Barril, na Ericeira (Sousa, 2010).

Os recursos disponíveis nas proximidades do Casal do Outeiro terão influenciado a sua implantação nesta plataforma junto ao rio, que proporcionaria o acesso a matérias-primas, práticas agrícolas e pastorícia, bem como um controlo fluído da paisagem e meios de penetração para regiões interiores

\section{DESCRIÇÃO DO SÍTIO}

Foi o tipo de implantação e meio envolvente em que este aparente pequeno núcleo habitacional se terá desenvolvido, que nos levaram a efectuar prospecções nesta área, conduzindo posteriormente à identificação do mesmo (Figura 3).

O sítio apresenta actualmente um uso do solo agrícola, com plantação de batata, situando-se bastante próximo (20om) de um pequeno casal agrícola.

Aquando das prospecções (Janeiro de 2020), a visibilidade do solo era razoável, sendo especialmente visíveis os materiais após as chuvas. Para o panorama regional, podemos considerar que a visibilidade do solo era superior à da generalidade dos contextos de habitat da região (Sousa, 2009).

Os materiais surgiram dispersos numa área relativamente extensa (120 por 6om, no total de 720om2) (Figura 1) não se registando grandes concentrações de material. À superfície não foi detectada qualquer especificidade de coloração do solo ou micro-relevo que indicasse a presença de estruturas, mas deve salientar-se o uso agrícola destes terrenos.

\section{A CULTURA MATERIAL DE CASAL DO OUTEIRO}

O conjunto artefactual recolhido é relativamente pequeno, contudo é bastante significativo para que se possa efectuar uma leitura e identificação cronológica. Todos os materiais presentes na tabela (ver tabela 1) correspondem a recolhas de superfície, salientando-se a representatividade da indústria lítica. Pode colocar-se a hipótese de o sílex ter mais visibilidade, sobretudo no Inverno após as chuvas.

Face ao tipo de espólio, podemos aventar que Casal do Outeiro apresenta vestígios de um contexto doméstico de pequena/média dimensão. A escassez da cerâmica pode indicar uma utilização pouco prolongada. A indústria lítica é composta essencialmente de sílex $(76 \%)$, seguindo-se o quartzito ( $15 \%$ ) e o quartzo (9\%). É possível determinar que no local, com base na presença de material de preparação, reavivamento e de um núcleo poliédrico, seriam executadas tarefas de trabalho de sílex, nomeadamente o talhe da pedra para obtenção de utensilagem.

A debitagem regista a presença de suportes alongados (pequenas lâminas e lamela) e, em número mais expressivo, lascas. As três lâminas apresentam larguras entre os 13 e os $14 \mathrm{~mm}$, sendo estreitas e di- 
reitas, de bordo paralelo e secção trapezoidal (2) e triangular (1). Os dois fragmentos proximais de lâmina apresentam talão liso, não estando retocadas.

Relativamente à utensilagem, a mesma não é muito vasta ou diversificada, contudo, adequa-se à tipologia de artefactos encontrados em contextos habitacionais, como Penedo do Lexim (Mafra) onde se verifica a aproximação dimensional de lamelas e lâminas e escassos artefactos retocados (Sousa, 2003:331).

Entre os utensílios, regista-se a presença de possíveis evidências de actividade agrícola, nomeadamente um fragmento de lâmina com lustre de cereal (Fig. 7, ENC.054.01) e um denticulado (Fig. 7, ENC.054.08). O referido denticulado regista tratamento térmico e pode indicar uma cronologia mais antiga, atendendo à presença de retoque abrupto, quase abatido. Também um dos raspadores (Fig. 7 , ENC.054.10) apresenta vestígios claros de utilização no bordo esquerdo. Apenas com estudos traceológicos seria possível confirmar esta leitura macroscópica. Está ainda documentada a presença de um furador largo sobre lasca (Fig. 7, ENC.054.09).

Quanto às técnicas de talhe, uma análise preliminar poderia indicar talhe por percussão directa e indirecta. Contudo, as dimensões e uniformidade dos suportes alongados reduzidas das peças sugerem na verdade a debitagem de produtos por pressão, questão que aliás tem vindo a ser interpretada e debatida por outros autores em conjunto líticos como no concheiro O Meu Jardim (Nazaré) (Carvalho, 1998 e Valera, Carvalho e Goufa, 2017:10, 15-16). Também a reduzida largura das lâminas poderá ser um indicador da tendência arcaizante deste conjunto, uma vez que, as produções laminares tendem a evoluir de forma robusta e amplamente notória no Neolítico final e Calcolítico (Carvalho, 1995; Sousa, 2010; Cardoso, Sousa e André, 2015).

Em estudo geoarqueológico realizado por P. Jordão e N. Pimentel é registada a presença de áreas de aprovisionamento de sílex nos terraços do rio Sizandro (Jordão e Pimentel, 2019). A análise efectuada pelos autores citados sobre os terraços quaternários do Sizandro permitiu detectar a presença de sílex gerado em diferentes condições ambientais (Jordão e Pimentel, 2019:46). Nota-se a ferruginização do córtex, algo que parece ser evidente nos estratos mais antigos dos terraços quaternários superiores do rio Sizandro onde está atestada a presença de clastos siliciosos (Jordão e Pimentel, 2019:49). Na bacia de Runa, com formações do Cenomaniano, foi compro- vada a presença de níveis de sílex avermelhado nos calcários brancos e rosados, apresentando texturas mudstone (Jordão e Pimentel, 2019:50). Podemos colocar a hipótese que a origem de proveniência do sílex do Casal do Outeiro se localize nos depósitos secundários aluviais do Sizandro, distando menos de $20 \mathrm{~km}$ deste local. Apenas um estudo petrográfico do espólio do Casal do Outeiro e um levantamento geoarqueológico do seu entorno poderia confirmar as fontes de aprovisionamento deste povoado.

A presença de materiais de pedra polida reforça a cronologia neolítica do conjunto. Registou-se a presença de três fragmentos: um gume de enxó (Fig. 8, ENC.054.18) e um fragmento indeterminado de secção subrectangular (Fig. 8, ENC.054.20), ambos de anfibolito, e um talão de artefacto indeterminado de secção circular em rocha metamórfica (Fig. 8, ENC.054.19).

O uso de rocha metamórfica de possível proveniência do maciço sub-vulcânico de Sintra, também designada por xistos do Ramalhão (Cardoso e Carvalhosa, 1995), está largamente documentada na pedra polida da Baixa Estremadura, nomeadamente no Penedo do Lexim e nos povoados do $4^{\circ}$ e $3^{\circ}$ milénio da Ribeira de Cheleiros (Sousa, 1998). Verifica-se assim a possível aquisição de matéria nas proximidades de Sintra, numa zona mais próxima, mas também trocas comerciais com a região do Alentejo para obtenção de anfibolito.

A cerâmica é muito escassa, registando-se 15 fragmentos de cerâmica pré-histórica que não permitem de forma alguma a sua determinação tipológica, um bordo liso (Fig. 8, ENC.054.21) e um bordo denteado. Relativamente ao fragmento de bordo denteado (Fig. 8, ENC.054.22)., o mesmo tratar-se-á de uma forma aberta, tipo taça, com diâmetro interno máximo de $13 \mathrm{~cm}$, cuja aplicação se encontra na face externa mais próxima do bordo. A peça apresenta um bordo regular recto de pasta homogénea e semicompacta de superfície interna alisada e externa ligeiramente rugosa. Relativamente aos componentes não plásticos é visível a presença de micas numa pasta bastante depurada A decoração no bordo terá sido efectuada com recurso a um instrumento de secção angulosa uma vez que apresenta motivo em "v" de ondulação muito suave. Com as devidas prudências, a presença de um bordo denteado é especialmente importante para uma aproximação à cronologia do Casal do Outeiro. Desde K. Spindler que os bordos denteados têm sido referenciados como um dos fósseis directores do 
denominado "grupo da Parede" (Spindler, 1976), usando como sítio epónimo a Parede, sítio com enormes lacunas de registo estratigráfico, agrupando-se no referido grupo uma diversidade de sítios que possivelmente não são sincrónicos (cf. discussão em Gonçalves, 1995). Ainda que os bordos denteados não sejam exclusivos do Neolítico final, estando documentados no Neolítico antigo e até da Idade do Bronze, a tipologia de bordos denteados ou entalhados surge associada essencialmente a taças e a outras formas em povoados bem datados da transição $4^{\circ}$ / $3^{\circ}$ milénio na Península de Lisboa, nomeadamente em Leceia (Cardoso et al, 1996), Vale de Lobos (Valente, 2006) ou Serra das Éguas/ Espargueira (Encarnação, 2010).

Uma leitura global sobre o conjunto artefactual parece indicar a inserção de Casal do Outeiro numa

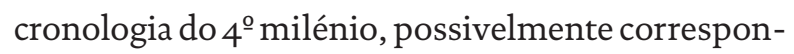
dendo à segunda metade, no Neolítico final. Numa leitura preliminar, consideram-se as presenças e as ausências dos materiais recolhidos até ao momento. Assim, não foi recolhido qualquer material de pedra lascada foliáceo (pontas de seta ou ovoides) e também estão ausentes as típicas cerâmicas decoradas do $3^{\circ}$ milénio (copos e taças caneladas, grupo folha de acácia ou campaniforme). A reduzida largura dos suportes alongados, a pedra polida, a cerâmica lisa e o bordo denteado podem corroborar a atribuição cronológica aqui preliminarmente efectuada.

Quanto à funcionalidade do sítio, a presença de elementos de pedra polida e elementos de foice, mesmo que num núcleo habitacional de menores dimensões, evidencia só por si a atribuição de um caracter mais permanente ao sítio, uma vez que, implicava a realização das actividades do quotidiano a que estes artefactos de associavam e a necessidade de utilização dos mesmos de forma recorrente.

A análise da funcionalidade de Casal do Outeiro pode também estar relacionada com a debitagem do sílex, tal como sucedeu para o povoado do Neolítico final do Carrascal (Cardoso, Sousa e André, 2015: 159) onde se regista a presença de abundantes vestígios de talhe local do sílex, num contexto misto de atelier e habitat semi-permanente. No Carrascal, as estruturas são escassas e a cultura material está esmagadoramente representada pelos materiais de talhe de sílex local (idem, ibidem).

Em contraste, nos povoados mais permanentes como Penedo do Lexim, Leceia e Vale de Lobos, as evidências de talhe local são mais circunscritas, evidenciando já a existência de uma mais complexa cadeia de obtenção de matéria-prima, com segmentação espacial da cadeia operatória (Sousa, 2010). De forma similar ao que se passa no Carrascal, também no Casal do Outeiro existe uma maior predominância de lascas, sendo elas não retocadas, enquanto no Penedo do Lexim e Leceia, existe o predomínio claro de suportes alongados tipo lamela e lâmina (Cardoso, Sousa e André, 2015:164 e Sousa, 2010).

\section{EM TORNO DO CASAL DO OUTEIRO: ALGUNS PONTOS NO MAPA E MUITOS VAZIOS}

Na área envolvente ao Casal do Outeiro, o estudo do povoamento neolítico e calcolítico tem diferentes percursos de investigação. Em Mafra, na freguesia da Encarnação onde se situa este sítio são escassos os sítios arqueológicos reportados em todas as cronologias, evidenciando de alguma forma, uma maior intensidade de investigações e de arqueologia preventiva no Sul do concelho (Sousa, 2010). Ao invés, em Torres Vedras, na bacia hidrográfica do Sizandro, a pesquisa arqueológica é muito intensa, desde as pesquisas de Manuel Heleno em jazidas do Paleolítico Superior (Zilhão, 1995) (Figura 6), às recolhas de Leonel Trindade (Trindade, Schubart e Sangmeister, 1965) e, naturalmente, as intensas pesquisas desenvolvidas pelo Instituto Arqueológico Alemão a partir de 1964 (Sangmeister e Schubart, 1981), partindo do Castro do Zambujal (Kunst, 1987) mas sempre com uma perspectiva territorial (Kunst e Trindade, 1991).

A Norte na bacia hidrográfica do Sizandro são abundantes os vestígios de ocupação pré-histórica. $O$ vale do Sizandro apresenta essencialmente vestígios do $3^{\circ}$ milénio, muito provavelmente tendo como lugar central do Castro do Zambujal, que dista apenas $7 \mathrm{~km}$ do Casal do Outeiro. Na parte mais interior do vale do Sizandro concentram-se vários povoados calcolíticos como Fórnea, Penedo ou Achada, mas neste caso a informação disponível é reduzida e antiga.

As fases mais recuadas do Neolítico estão muito mal representadas em Torres Vedras (Dambeck et al, 2015; Zilhão, 2016), apenas reportadas pontualmente em Vale da Mata, Baío e Cova da Moura. A esse respeito, os estudos paleobotânicos desenvolvidos pela equipa dirigida por Michael Kunst, vieram documentar a presença do cultivo de práticas agrícolas, com o desaparecimento do coberto vege- 
tal com carvalhos e o aparecimento de evidências de cultivo cerealífero a partir da segunda metade do $6^{\circ}$ milénio (Dambeck et al, 2015: 392). A referida equipa avança para fenómenos geoarqueológicos para explicar a ausência de povoamento neolítico, com a erosão do solo e deposições ulteriores de sedimento, ocultando os contextos arqueológicos situados em áreas abertas ou em encosta (idem, ibidem).

Também para o povoamento do Neolítico final se regista este vazio de informação que é aliás comum a toda a região do Oeste (Figura 5), com escassos indícios nos níveis subjacentes dos povoados fortificados como sucede na Ota (Texugo, 2016). O Sizandro e o Oeste são assim marcados por uma escassez de povoamento neolítico ( $6^{\circ}$ ao $4^{\circ}$ milénio) que contrasta com o mundo funerário, nomeadamente as grutas naturais como a Cova da Moura ou o hipogeu do Cabeço da Arruda, que dista apenas $8 \mathrm{~km}$ do Casal do Outeiro.

Face ao vazio arqueológico em torno do Casal do Outeiro, a presente equipa efectuou prospeções complementares na área envolvente, tendo sido detectados outros sítios que poderão de forma directa ou indirecta estar relacionados com este núcleo.

Assim, foram registados um conjunto de grutas e abrigos situados nas encostas calcárias da área de Marvão (Mafra), ao longo do vale da ribeira de Safarujo a escassos 4,5 km do Casal do Outeiro. Os abrigos apresentam sedimentação mas na sua generalidade não registam qualquer material à superfície o que não invalida a presença antrópica antiga nestas cavidades.

Foram apenas recolhidas à superfície duas cerâmicas manuais no Abrigo da Moita Longa, inserido numa bancada calcária com uma pala pétrea como tecto. No local existe bastante sedimento que se acumula praticamente até poucos centímetros do tecto da laje calcária onde foram identificadas cerâmicas (Fig. 9. ENC.057.01 e 02). Este abrigo insere-se numa área calcária com larga presença de grutas e abrigos que podem eventualmente, mediante trabalhos aprofundados, vir a fornecer novos dados que podem traduzir ocupação doméstica ou, mais provavelmente, funerária (Figura 4).

$\mathrm{Na}$ área envolvente aos abrigos de Marvão regista-se a presença de materiais que parecem indicar uma ocupação neolítica na área envolvente. Trata-se de materiais isolados, não sendo possível determinar se correspondem a sítios efectivos ou a materiais em posição secundária:
1. Na margem direita do Safarujo, a menos de $1 \mathrm{~km}$ do Abrigo da Moita Longa, foram identificadas em Valongo de Baixo uma lasca retocada e uma lamela em sílex e um fragmento de cerâmica manual (Fig. 9. ENC.056.01 e 02);

2. Registou-se a presença de outros materiais pré-históricos na Ameixoeira, tendo sido identificados vários elementos em sílex relacionados com as várias fases de debitagem do sílex (restos de talhe, flancos de núcleo e núcleo), utensilagem (um furador) e fragmento de xisto, sem que tenha sido verificada a presença de cerâmica (Fig. 9. ENC.058.01 a 04).

3. Na Arieira, foi identificado um pequeno núcleo em sílex (Fig. 9. ENC.055.01);

4. Na Quinta dos Machados - Picanceira 2 foram também recolhidos materiais líticos, salientando a presença de um bordo cerâmico brunido que remete para a presença de cronologias da Idade do Bronze (Fig. 9. ENC.059.01 a 03).

Casal do Outeiro não parece estar assim isolado, podendo antever-se uma rede de povoamento que apenas agora começa a ser identificada. A visibilidade dos contextos arqueológicos na Estremadura é muito difícil aliando-se a uma intensa ocupação antrópica e ao uso do solo. Assim, mesmo que reduzidos os materiais recolhidos, é de destacar a importância do povoamento agora identificado no Norte do concelho de Mafra.

\section{CONCLUINDO. CASAL DO OUTEIRO E O POVOAMENTO DO NEOLÍTICO FINAL DAS PENÍNSULAS DE LISBOA E SETÚBAL}

Nas Penínsulas de Lisboa e Setúbal, tal como na generalidade do Centro e Sul de Portugal, o conhecimento do povoamento neolítico centra-se nos inícios (transição $6^{\circ} / 5^{\circ}$ milénio) e na fase final prévia ao aparecimento das primeiras fortificações e da metalurgia do cobre (transição $4^{\circ} / 3^{\circ}$ milénio). Sabemos pouco dos momentos intermédios, no que se generalizou designar como Neolítico médio (Neves e Diniz, 2014; Silva e Soares, 2018), sendo provável que para sítios sem datações absolutas possa existir uma natural acumulação das classificações nos limites do balizamento cronológico.

Numa perspectiva diacrónica deve ser realçado que partir de meados do $3^{\circ}$ quartel do $4^{\circ}$ milénio se verifica uma verdadeira "explosão" de sítios, povoados e necrópoles. Nesta fase, com a consolidação das 
primeiras sociedades camponesas, parece registar-se um momento de viragem, possivelmente relacionado com a intensificação das práticas agrícolas e pastoris.

Este momento de aceleração do processo de consolidação das sociedades camponesas está reflectido na Baixa Estremadura onde se regista um elevado número de ocorrências de povoamento, especialmente na região da actual área metropolitana de Lisboa. Toma-se como base de análise o inventário apresentado em Sousa, 2016/2017 (tabela 2), devendo apenas ser acrescentado o sítio do Paço (Delicado et al, no prelo) e o Casal do Outeiro.

É na região de Lisboa que se concentram 23 das 30 ocorrências da Baixa Estremadura, estando actualmente inventariadas nos concelhos de Mafra (3), Sintra (8), Oeiras (4), Loures (3), Lisboa (3), Cascais (1), Odivelas (1), Amadora (4). Permanece por compreender o vazio a Norte, na zona Oeste. Para além das explicações geoarqueológicas atrás mencionadas deve ser também realçada a diferente intensidade de investigação das duas regiões e também das diferenças quanto à intensidade da arqueologia preventiva e do impacto no solo.

Entre os sítios de habitat integráveis no Neolítico final podemos individualizar dois grandes grupos: as ocupações subjacentes às fortificações calcolíticas (Penedo do Lexim, Ota, Leceia, Olelas, Paço e, de alguma forma, Travessa das Dores) e os povoados abertos, frequentemente com várias ocupações do Neolítico e depois Calcolítico com campaniforme inciso (Negrais, Casas Velhas, Serra das Éguas, Vila Pouca, Montes Claros, Parede).

Para além das diferenças na biografia destes sítios, refira-se também as diferenças no tipo de implantação, registando-se elevações com grande visibilidade e controlo da paisagem (nomeadamente as pré-existências dos povoados fortificados) e áreas abertas sem preocupação defensiva, como é o caso do Casal do Outeiro. Do conjunto de povoados actualmente conhecidos para a Baixa Estremadura, 17 relevam uma implantação em elevação, 11 em vertente e 2 em área aplanada.

A implantação e a dispersão dos sítios integráveis no Neolítico final parece indicar a presença de um povoamento disseminado, possivelmente constituído por pequenos núcleos, por vezes localizando-se em área muito próxima, como sucede por exemplo em Oeiras (Leceia, Carrascal, Barotas) ou em Sintra (complexo de sítios de Negrais).
Sendo escassas as informações sobre a morfologia das estruturas de habitat e a funcionalidade dos sítios, parece plausível avançar com uma hipótese de um padrão de povoamento multifacetado, onde se evidencia a pulverização do povoamento e a multiplicidade dos recursos explorados (Sousa, 2010). $\mathrm{Na}$ generalidade dos sítios, registam-se estruturas frustes, mas cita-se a complexidade das estruturas recentemente identificadas na Travessa das Dores, com fosso, fossas, estruturas de alvenaria (Neto et $a l, 2019)$ o que pode indicar uma maior complexidade da morfologia de ocupação. No caso do Casal do Outeiro, apenas a realização de levantamento geofísicos e de ulteriores escavações poderá indicar o tipo de ocupação, mas a presença de um número significativo de materiais à superfície pode indicar algum nível de perturbação resultante dos trabalhos agrícolas.

Deve ainda referir-se à existência de sítios especializados, como a exploração de sal da Ponta da Passadeira (Soares, 2013) ou o concheiro do Magoito (Soares, 2003), referindo-se ainda possíveis locais especializados na extração e processamento inicial do sílex, como Casas de Baixo (Zilhão, 1994).

O número de sítios datados integráveis no chamado "Neolítico final" éainda muito reduzido, limitando-se a sete habitats: Leceia, Carrascal, Penedo do Lexim, Lameiras, Vale de Lobos, Serra das Éguas e Parede. É especialmente importante o balizamento cronométrico de Leceia e Vale de Lobos. Em Leceia, a existência de um hiato de ocupação entre a ocupação neolítica e o povoado fortificado permite uma boa definição dos parâmetros cronológicos, balizados entre 3510-2900 cal a.C. através de 7 datações (Cardoso e Soares, 1996). Vale de Lobos apesar do mau estado de conservação dos contextos, tem uma ocupação monofásica: as duas datações absolutas (Beta-220074 e Beta-220075), indicam um intervalo entre 3340 a $2820 \mathrm{cal}$ a.C. (Valente, 2006).

Temos mais sítios, mais datas e mais contextos estudados, mas ainda não está claro o processo de aceleração registado no último quartel do $4^{\circ}$ milénio. Não sabemos ainda se a ocupação do Casal do Outeiro se restringe temporalmente a este intervalo, existindo algum arcaísmo que pode indicar fases mais antigas. A avaliar pelos materiais de superfície, o sítio terá sido abandonado no $3^{\circ}$ milénio, mas essa será uma história em aberto, dependente de futuras novas pesquisas no Casal do Outeiro e no povoamento pré-histórico regional. 


\section{BIBLIOGRAFIA}

ALEIXO,C;RAMOS-PEREIRA,A;TRINDADE,J.(2014) - A Evolução das Condições Ambientais na Várzea de Maceira (Estuário do rio Alcabrichel, oeste de Portugal) no Holocénico Superior. In Formação e ocupação de litorais nas margens do atlântico - Brasil / Portugal. Edit: Silvia D. Pereira; Joana G. Freitas; Sergio Bergamaschi; Maria A. C. Rodrigues. Corbã Editora Artes Gráficas Lda, Rio de Janeiro. Capítulo V. pp. 85-98.

CARDOSO, J. L.; CARVALHOSA, A. B. (1995) - Estudos petrográficos de artefactos de pedra polida do povoado pré-histórico de Leceia (Oeiras). Análise de proveniências. Estudos Arqueológicos de Oeiras. Lisboa. 5, pp. 123-151.

JORDÃO, P.; PIMENTEL, N. (2019) - Os terraços quaternários do rio Sizandro (Torres Vedras): caracterização de uma área-fonte de sílex. Geonovas, V. 32, pp. 93-106.

CARDOSO, J. L.; SOARES, J; SILVA, C. T. (1996)-A ocupação neolítica de Leceia (Oeiras): materiais recolhidos em 1987 e 1988. Estudos Arqueológicos de Oeiras. Oeiras: Câmara Municipal de Oeiras.№6, pp. 47-91.

CARDOSO, J. L.; SOARES, A. M. M. (1996) - Contribution d'une série de datations C14, provenant du site de Leceia (Oeiras, Portugal), à la chronologie absolue du Néolithique et du Chalcolithique de l'Estemadura Portugaise. Actes du Colloque de Périgueux. Supplément à la Revue d'Archéométrie. Rennes, pp. 45-50.

CARVALHO, A. F. (1998) - O talhe da pedra e a transição Neolítico - Calcolítico no Centro e Sul de Portugal: tecnologia e aspectos da organização da produção. Trabalhos de Arqueologia da EAM. Lisboa. 3-4, pp. 41-6o.

DAMBECK, R.; KUNST, M.; THIEMEYER,H.; KALIS, A. J.; VAN LEEUWAARDEN, W.; HERRMANN, N. (2015) - Onde é que habitaram? Novos dados sobre a Neolitização retirados do exemplo do Vale do rio Sizandro (Torres Vedras, Portugal), in Gonçalves, V. S.; Diniz, M.; Sousa, A. C. (eds.) - 5. . Congresso do Neolítico Peninsular, Lisboa, Centro de Arqueologia da Universidade de Lisboa, pp. 385-396.

DAVEAU, S. (1980) - Espaço e Tempo. Evolução do ambiente geográfico de Portugal ao longo dos tempos pré-históricos. Clio . Lisboa. 2, pp. 13-37.

DELICADO, C., RENDEIRO,L.C.;LOPES,A.; PEREIRA, A. (no prelo) - O sítio pré-histórico do Paço (Peniche): uma varanda Calcolítica sobre o oceano. Revista Portuguesa de Arqueologia, 23.

DIAS, J. A. (1987) - Dinâmica sedimentar e evolução recente da plataforma continental portuguesa setentrional. Tese de Doutoramento em Geodinâmica Externa, apresentada à Faculdade de Ciências da Universidade de Lisboa. Policopiada, $384 \mathrm{p}$.
ENCARNAÇÃO, G. (2010) - As cerâmicas carenadas do povoado da Espargueira (Serra das Éguas, Amadora). Um contributo para o seu estudo. Tese de Mestrado em Arqueologia apresentada na Faculdade de Letras da Universidade de Lisboa.

GONÇALVES, V. S. (1995) - Sítios, horizontes e artefactos: leituras críticas de realidades perdidas. Cascais.

HOFFMANN, G. (1990) - Zur Holozänen Landschaftensentwicklung im tal des Rio Sizandro (Portugal). Madrider Mitteilungen. Mainz. 31 (1990) 21-33.

HOFFMANN, G.; SCHULZ, H. (1995) - Cambio de situación de la linea costera y estratigrafía del holoceno en el valle del río Sizandro/Portugal. In KUNST, M., ed. lit. - Origens, estruturas e relações das Culturas Calcolíticas da Península Ibérica : actas das I Jornadas Arqueológicas de Torres Vedras, 1987. Lisboa: IPPAR, 1995. (Trabalhos de Arqueologia ;7). pp. 45-46.

KUNST, M. (1987) - Zambujal. Glockenbecher und kerbblattverzierte Keramik aus den Grabungen 1964 bis 1973. Verlag Philipp von Zabern, Mainz, Madrider Beitrãge 5, 2.

KUNST, M. ; TRINDADE, L. (1991) - Zur Besiedlungsgeschitchte des Sizandrotals : ergebnisse aus der Kustenforshung. Madrider Mitteilungen. 31 (1991) 34-82.

NETO, N.; REBELO, P. \& CARDOSO, J. L. (2015) - O povoado do Neolítico Final e do Calcolítico da Travessa das Dores (Ajuda - Lisboa). Estudos Arqueológicos de Oeiras. Oeiras. 22, pp. 235-28o.

NEVES, C. e DINIZ, M. (2014) - Acerca dos cenários da acção: estratégias de implantação e exploração do espaço

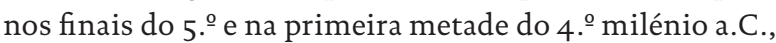
no sul de Portugal. Estudos do Quaternário. Braga. 11, pp. $45-58$.

VALENTE, A. (2006) - Cerâmicas com bordos denteados no Povoado de Vale de Lobos (Sintra). Lisboa. Dissertação de Mestrado apresentada à Faculdade de Letras da Universidade de Lisboa.

VAlerA, A. C.; CARVAlHO, A. F.; GOUFA, E. (2017) - O concheiro do Meu Jardim (Nazaré) no contexto das estratégias de produção e circulação de suportes lâmino-lamelares no Neolítico Médio da Estremadura Portuguesa. Journal of Lithic Studies. Edinburg: School of History, Classics and Archaeology, University of Edinburgh Vol. 4:3. pp. 1-24.

SANGMEISTER, E.; SCHUBART, H. (1981) - Zambujal: die Grabungen 1964 bis 1967. Mainz : Philipp von Zabern, 1981. (Madrider Beiträge ; Bd. 5).

SILVA, C. T. d. e SOARES, J. (2018) - Para o estudo do Neolítico Médio: o sítio da Fábrica de Celulose (Mourão). Revista Portuguesa de Arqueologia, 21. 5-23. ISSN o874-27-82. 
SOARES, A. M. M. (2003) - A duna de Magoito revisitada. Revista Portuguesa de Arqueologia. Lisboa. 6 (1), pp. 83-10o.

SOARES, J. (2013) - Sal e conchas na Pré-História portuguesa. O povoado da Ponta da Passadeira (estuário do Tejo). In SOARES, J. (ed.) - Pré-História das zonas húmidas. Setúbal Arqueológica. Setúbal. 14, pp. 171-196.

SOUSA, A. C. (1998) - O Neolítico final e o Calcolítico na área da Ribeira de Cheleiros. Lisboa (Trabalhos de Arqueologia; 11).

SOUSA, A. C. (2003) - O Neolítico final do Penedo do Lexim (Mafra). In GONÇALVES, V. ed - Muita gente, poucas antas. Lisboa: Instituto Português de Arqueologia. (Trabalhos de Arqueologia 25). pp. 305-338.

SOUSA, A. C. (2009) - Mapear o povoamento estremenho do 4. e 3. milénio a.C: Um caso de estudo e algumas reflexões sobre os processos de identificação. Estudos Arqueológicos de Oeiras. Oeiras: Câmara Municipal de Oeiras, 223-236.

SOUSA, A. C. (2010) - O Penedo do Lexim e o povoamento Neolítico final e Calcolítico da Península de Lisboa. Tese de doutoramento apresentada à Faculdade de Letras da Universidade de Lisboa. Exemplar policopiado. 2 vols.

SPINDLER, K. (1976) - Die Neolithishe Parede Gruppe In Mittelportugal. Madrider Mitteilungen 17: 21-75.

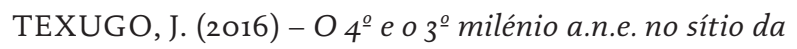
Ota (Alenquer): Perscrutando por entre colecções antigas e projectos recentes. Dissertação de Mestrado em Arqueologia apresentada à Faculdade de Letras da Universidade de Lisboa.

TRINDADE, L.; SHUBART, H.; SANGMEISTER, E. (1965) - Escavações no castro eneolítico do Zambujal (Torres Vedras - Portugal).

ZILHÃO, J. (1994) - A oficina de talhe neo-eneolítica de Casas de Baixo (Caxarias, Vila Nova de Ourém). Trabalhos de Arqueologia da EAM. Lisboa. 2, pp. 35-45.

ZILHÃO, J. (1995) - O Paleolítico Superior da Estremadura Portuguesa. Lisboa: Colibri. 2 vols.

ZILHÃO, J. (2016) - O Neolítico Antigo de Vale da Mata (Cambelas, TorresVedras), in SOUSA, A.C.; CARVALHO, A.; VIEGAS, C. (eds.) - Terra e Água. Escolher sementes, invocar a Deusa. Estudos em Homenagem a Victor S. Gonçalves. Estudos \& Memórias 9, Lisboa, UNIARQ/FL-UL, pp. 97-111. 


\begin{tabular}{|c|c|}
\hline PEDRA LASCADA & № \\
\hline \multicolumn{2}{|l|}{ Matéria-prima } \\
\hline Termoclastos em quartzito & 3 \\
\hline Seixo em quartzito & 1 \\
\hline \multicolumn{2}{|l|}{ Núcleos } \\
\hline Núcleo de lascas em sílex & 1 \\
\hline \multicolumn{2}{|l|}{ Material de preparação e reavivamento } \\
\hline Flanco de núcleo em sílex & 6 \\
\hline \multicolumn{2}{|l|}{ Produtos de debitagem } \\
\hline Fragmento de lâmina em sílex & 1 \\
\hline Fragmento de lâmina em quartzo translúcido & 1 \\
\hline Lamela em sílex & 1 \\
\hline Lasca cortical em sílex & 2 \\
\hline Lasca em sílex & 3 \\
\hline Lasca em quartzo leitoso & 2 \\
\hline \multicolumn{2}{|l|}{ Restos de talhe } \\
\hline Restos de talhe em sílex & 7 \\
\hline \multicolumn{2}{|l|}{ Utensílios } \\
\hline Lâmina em sílex com lustre de cereal & 1 \\
\hline Raspadeira em sílex & 3 \\
\hline Furador em sílex & 1 \\
\hline Denticulado sobre lasca & 1 \\
\hline \multicolumn{2}{|l|}{ PEDRA AFEIÇOADA } \\
\hline Percutor em quartzito & 1 \\
\hline \multicolumn{2}{|l|}{ CERÂMICA } \\
\hline Bordo denteado & 1 \\
\hline Bordo & 1 \\
\hline Fragmentos cerâmicos & 15 \\
\hline \multicolumn{2}{|l|}{ PEDRA POLIDA } \\
\hline Fragmento de gume de enxó em rocha metamórfica & 1 \\
\hline Talão de utensílio em anfibolito & 1 \\
\hline Fragmento de utensílio em rocha metamórfica & 1 \\
\hline TOTAL & 55 \\
\hline
\end{tabular}

Tabela 1 - Amostra de materiais arqueológicos recolhidos em contexto de superfície. 


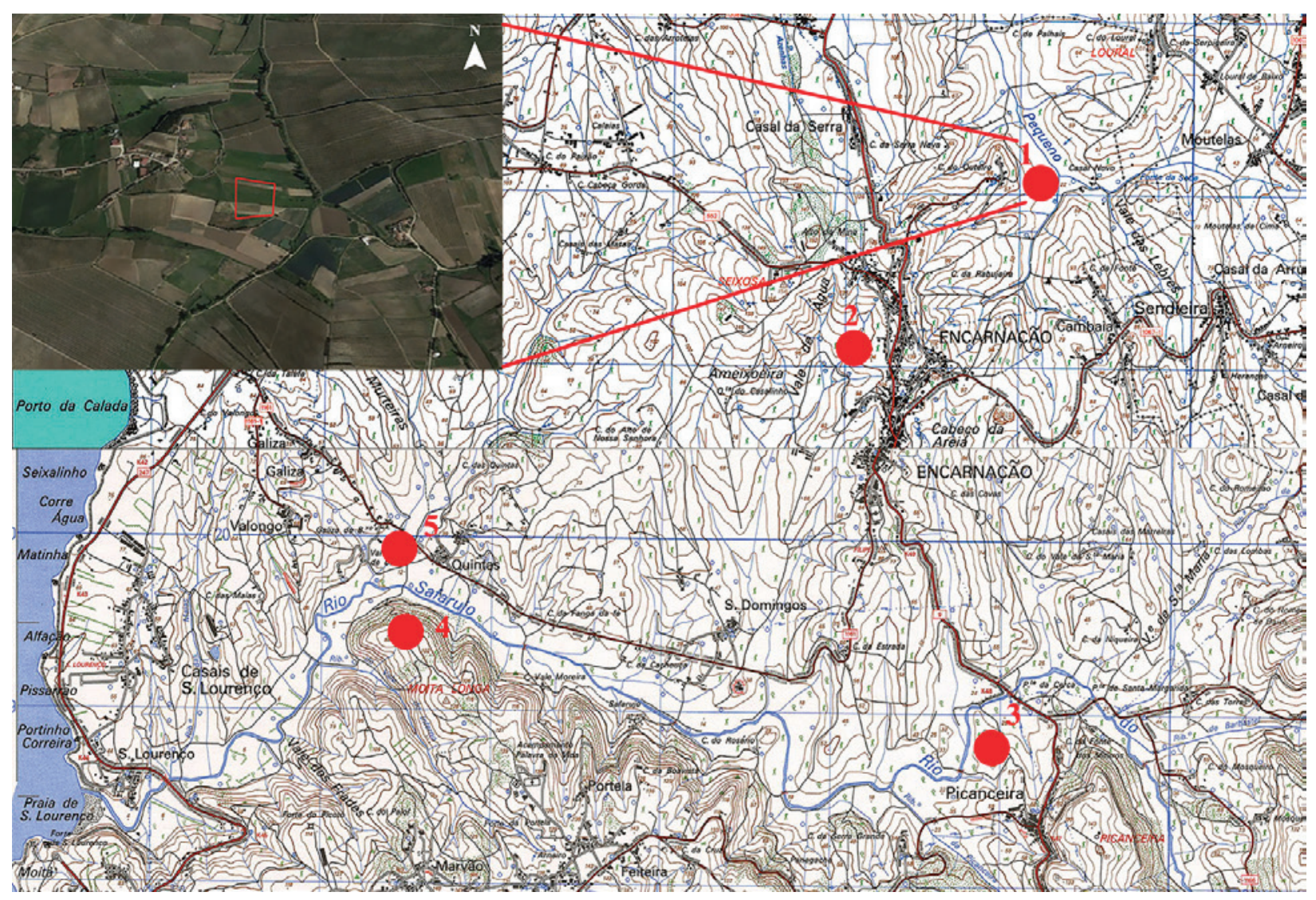

Figura 1 - Localização do sítio do Casal do Outeiro (1) e restantes identificados nas imediações (2 - Ameixoeira; 3 - Quinta dos Machados Picanceira 2; 4 - Abrigo da Moita Longa e 5 - Valongo de Baixo) na Cartografia Militar nº 374 e 388, escala 1:25 ooo. Pormenor da dispersão de materiais arqueológicos representada pelo rectângulo a vermelho. 

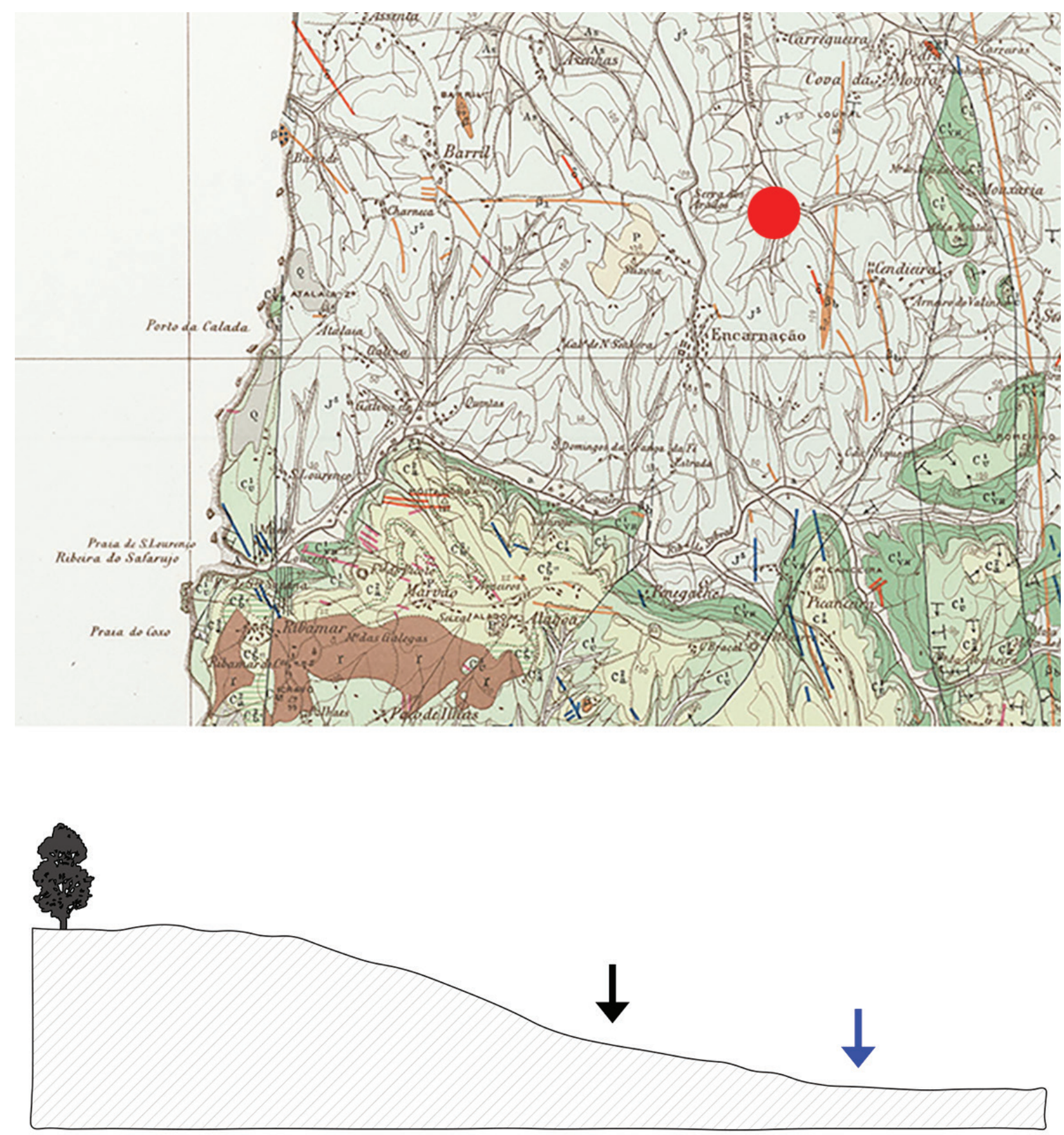

Figura 2 - Localização do Casal do Outeiro nas camadas do Portlandiano (J5) na Cartografia Geológica de Portugal, carta zo-C e altimetria do terreno com localização do sítio (a preto) e Ribeira da Carregueira (a azul). 


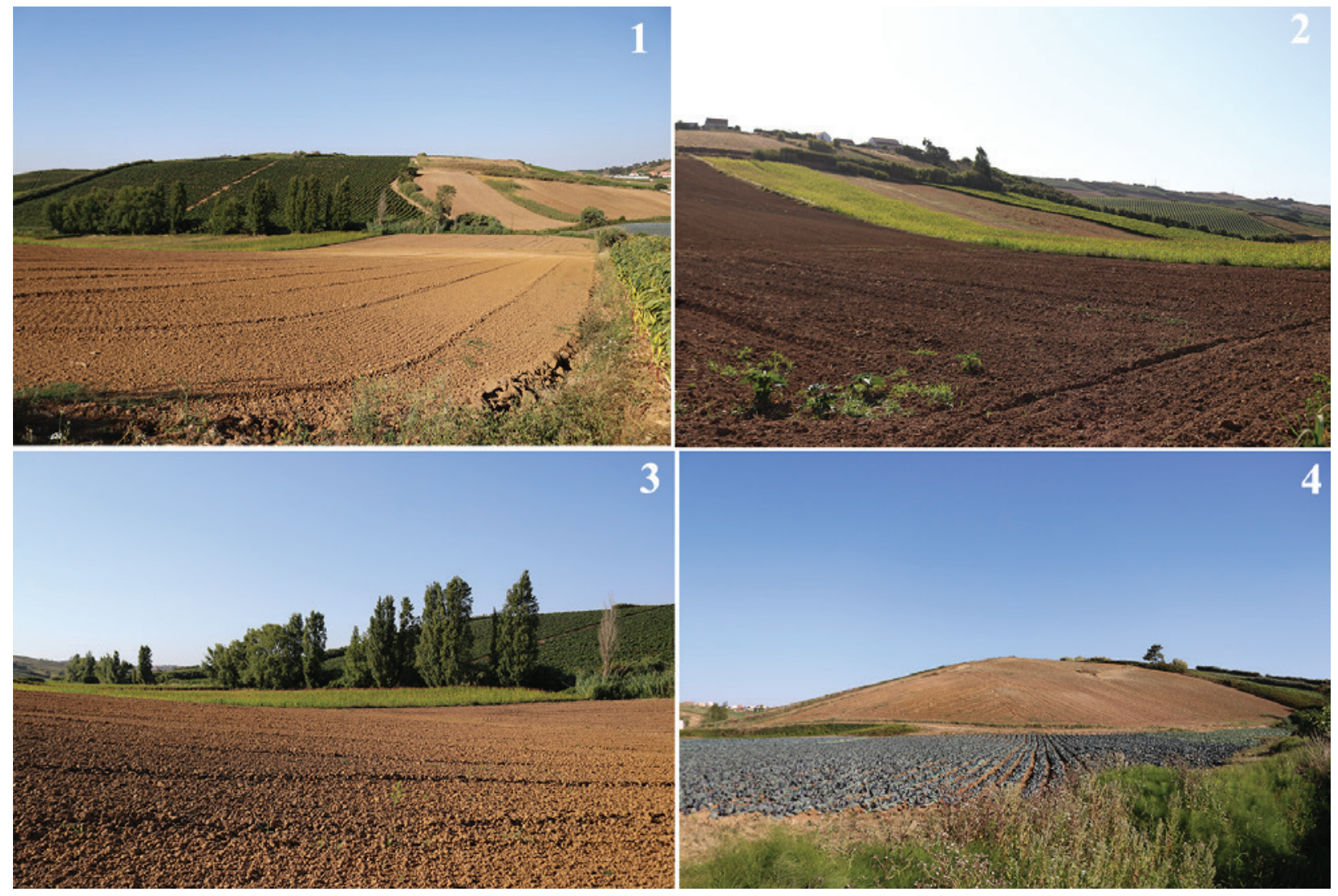

Figura 3 - Aspecto do sítio arqueológico do Casal do Outeiro. 1: vista do topo da elevação para Oeste junto da ribeira da Carregueira; 2: vista para Norte da elevação (ao lado esquerdo) e do terreno onde foram detectados os materiais arqueológicos. 3: vista sentido Nordeste, demonstrando ser um terreno de relevo suave encaixado entre elevações. 4: aspecto geral da área envolvente ao sítio arqueológico.

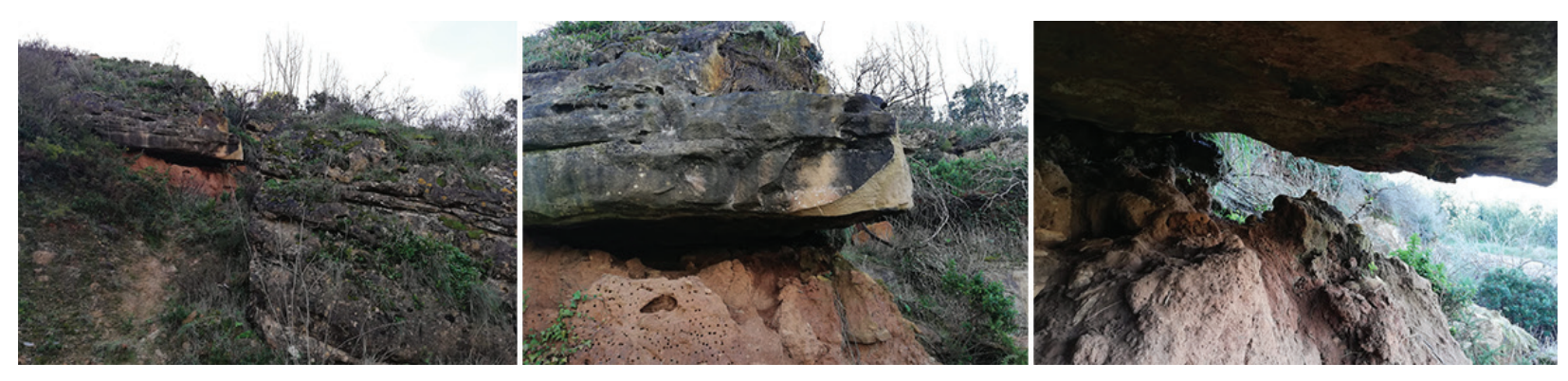

Figura 4 - Vista geral e aproximada do Abrigo da Moita Longa localizado nas escarpas calcárias de Marvão (Mafra). 


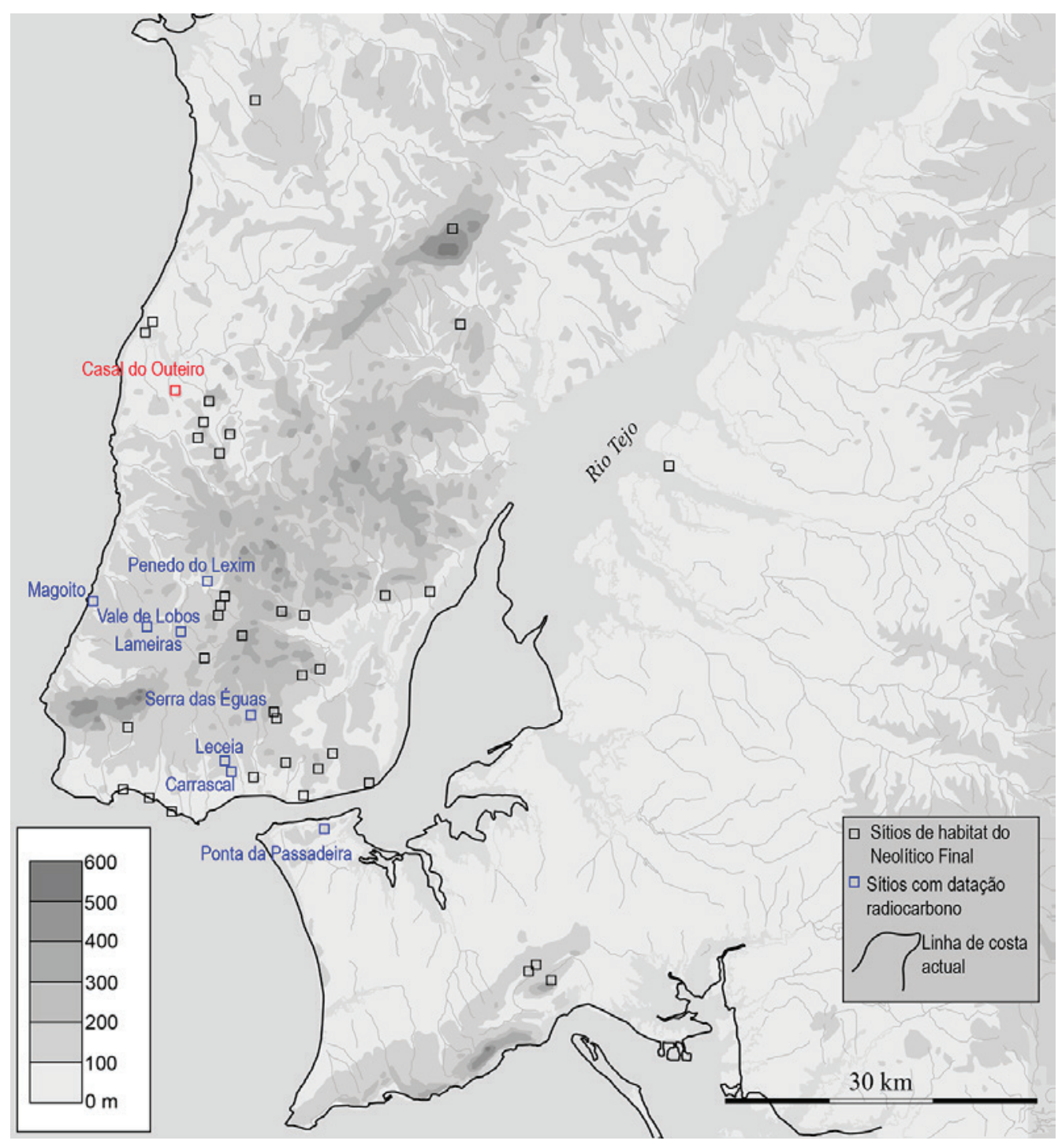

Figura 5 - Sítios de habitat do Neolítico final na região de Lisboa. Base Cartográfica Maya Langley e Rui Boaventura.

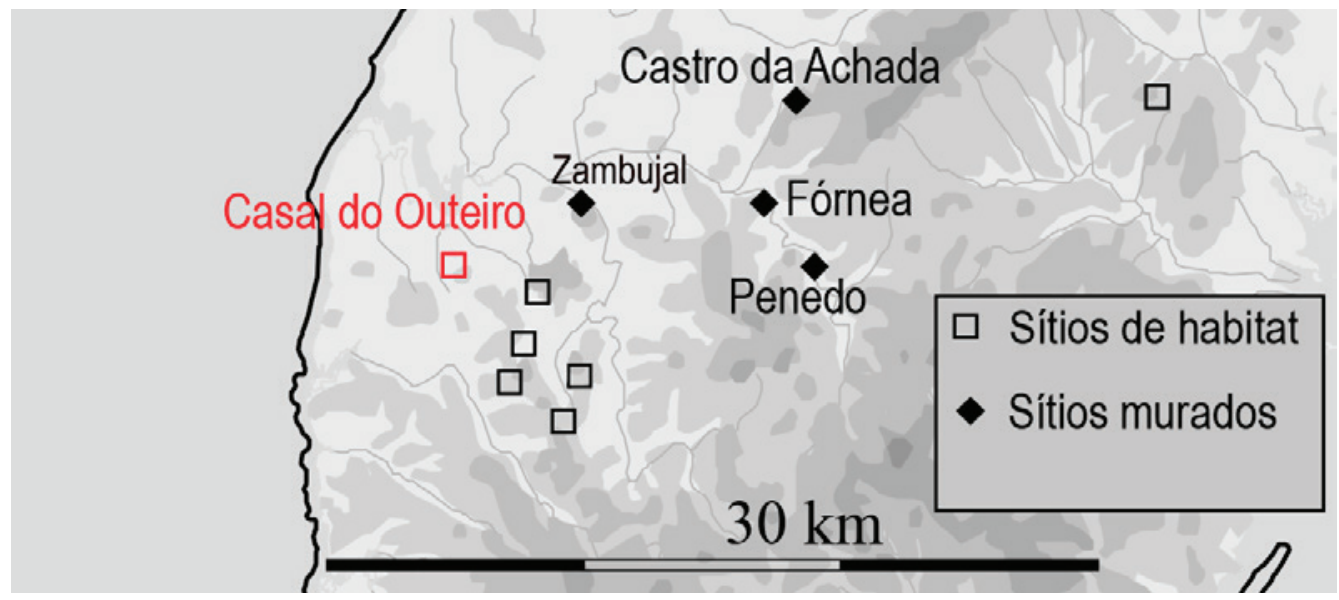

Figura 6 - Sítios de habitat e sítios murados na área envolvente ao Casal do Outeiro. Base Cartográfica Maya Langley e Rui Boaventura. 

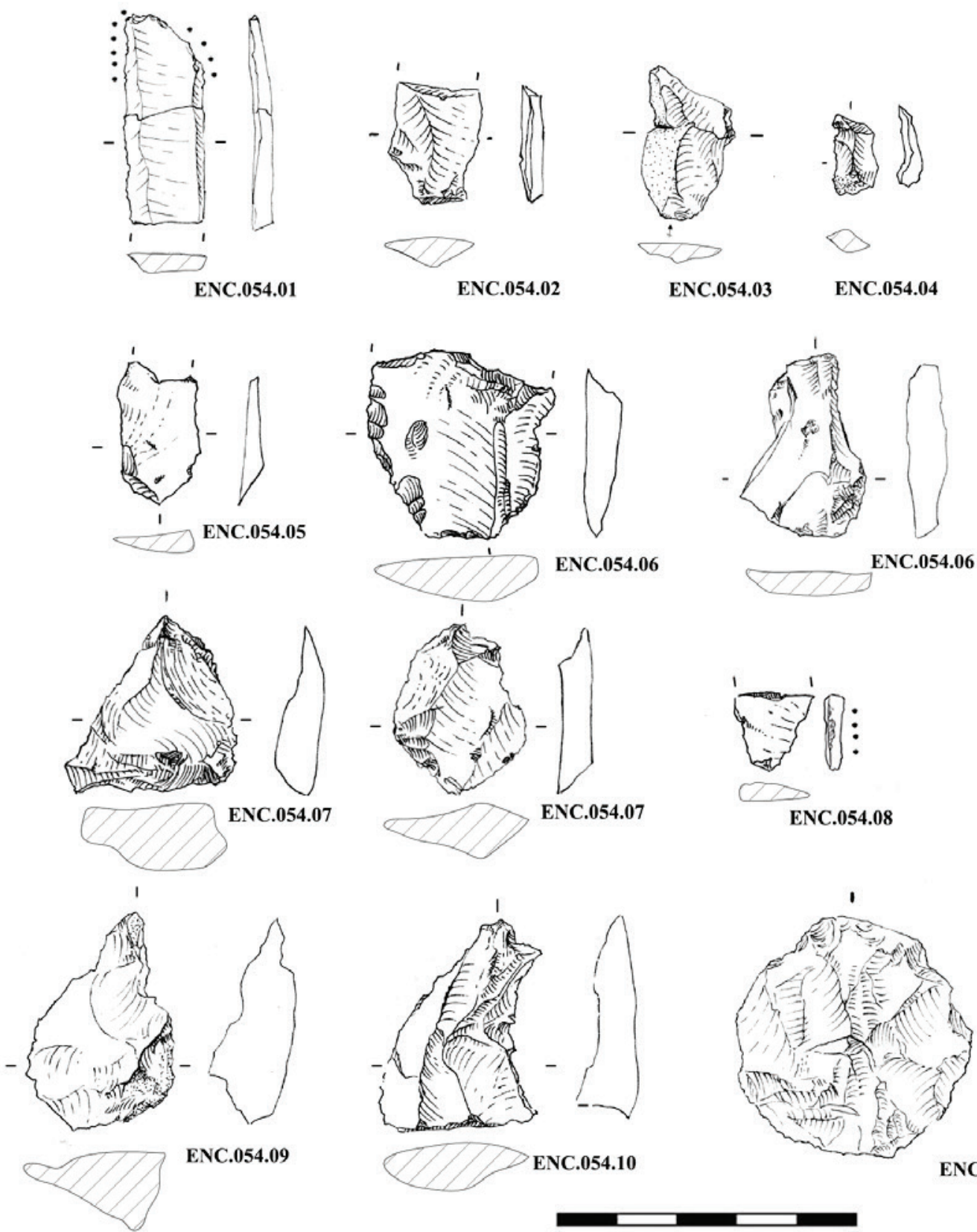

ENC.054.09
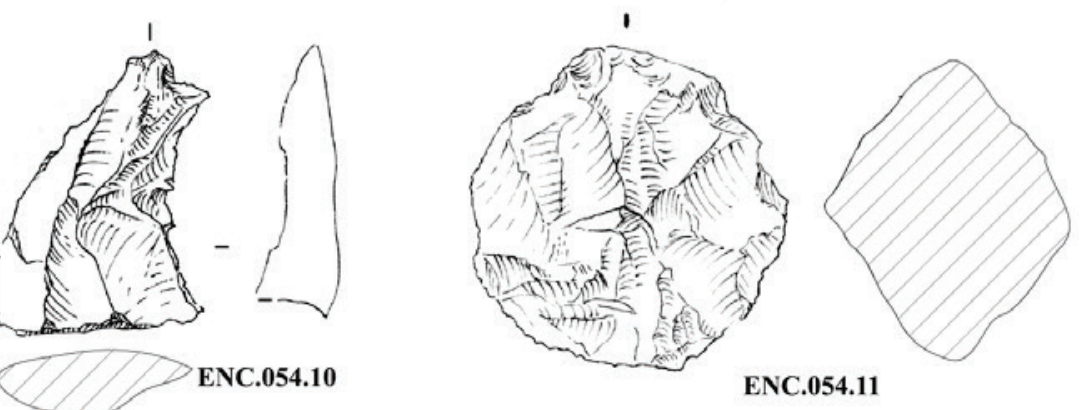

ENC.054.11
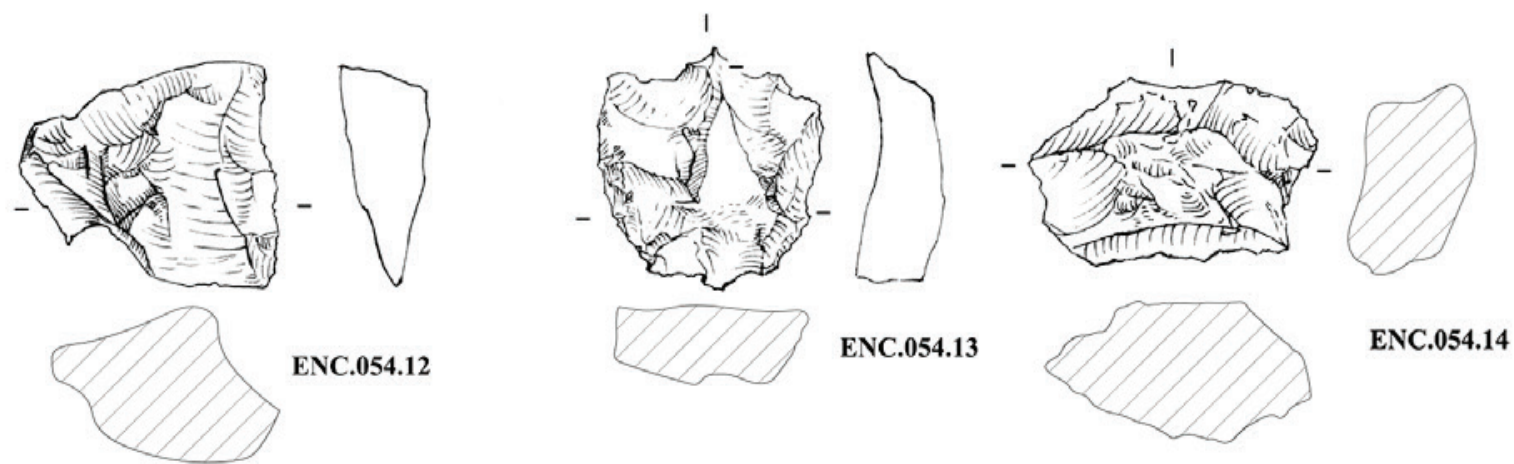

Figura 7 - Indústria lítica do Casal do Outeiro. Desenhos de Paula Bívar de Sousa. 


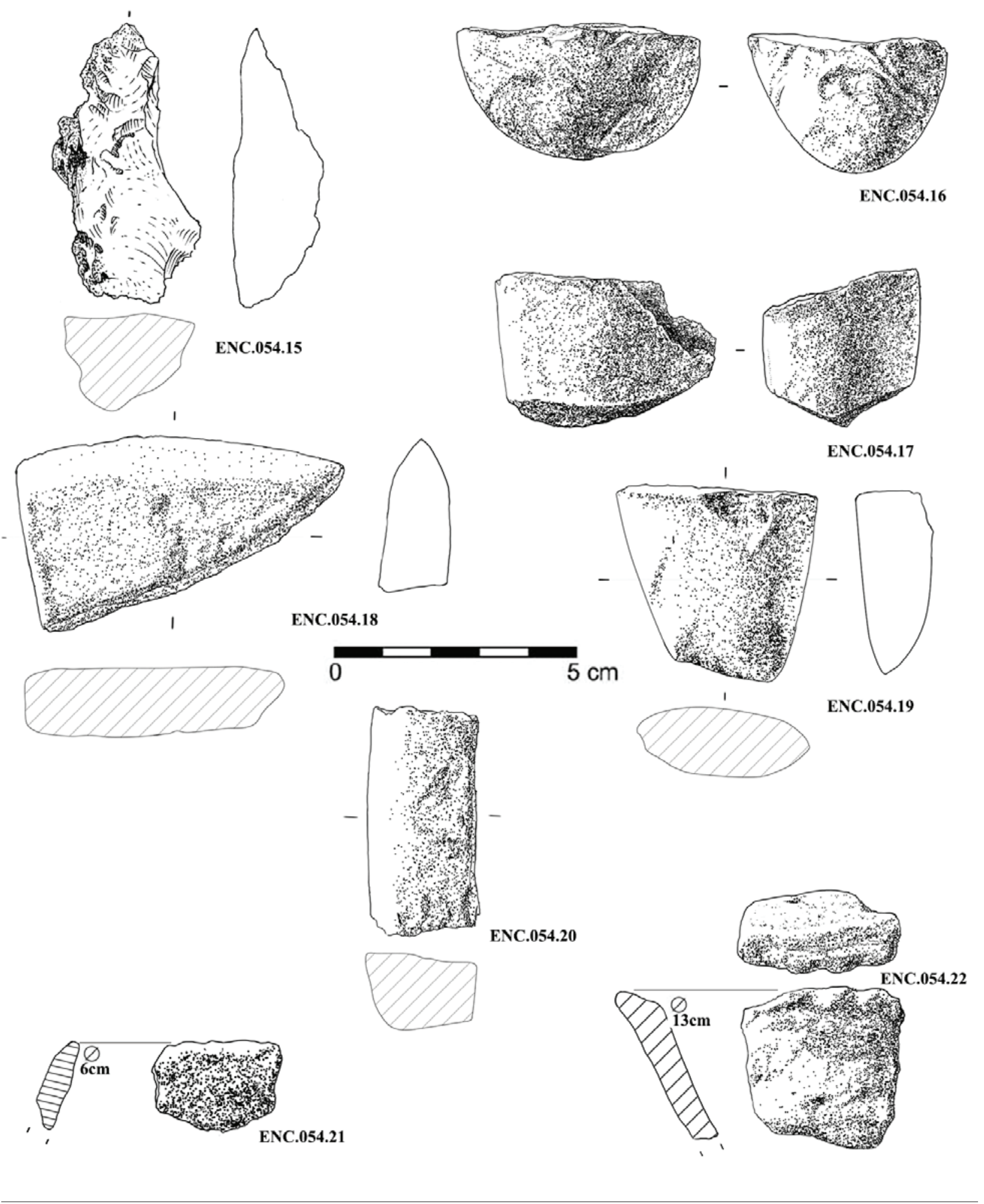

Figura 8 - Indústria lítica, pedra polida e cerâmica do Casal do Outeiro. Desenhos de Paula Bívar de Sousa. 

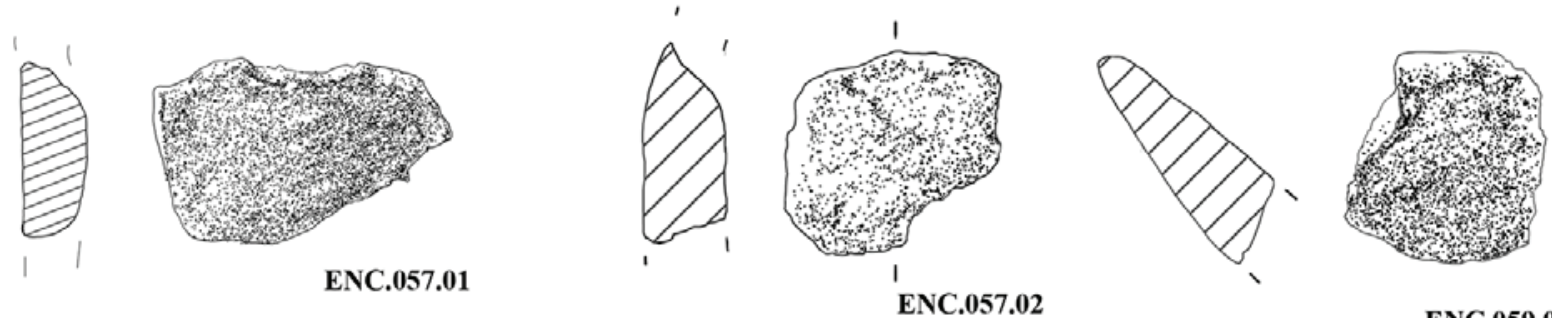

ENC.059.01
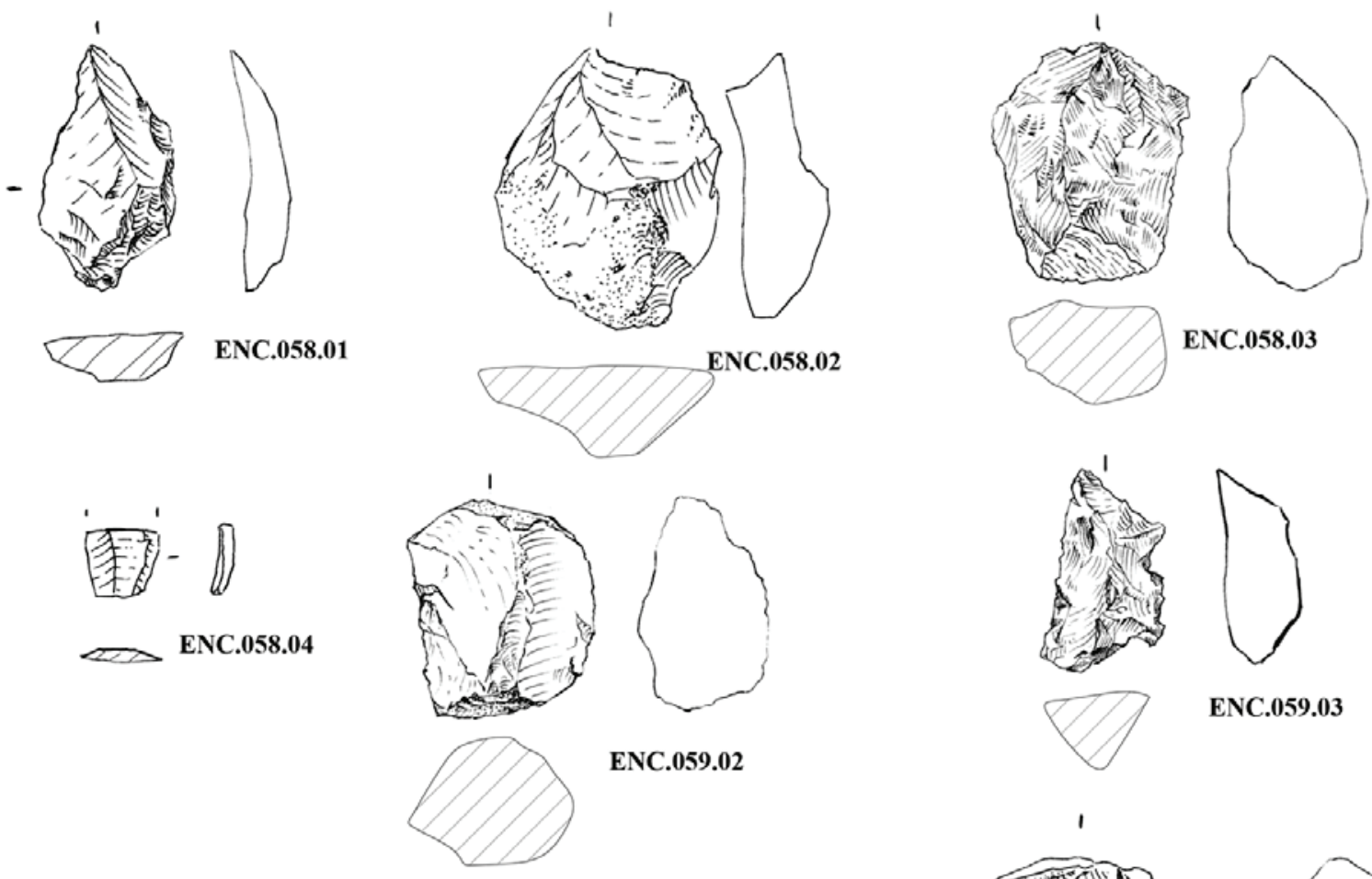

ENC.059.02

ENC.059.03
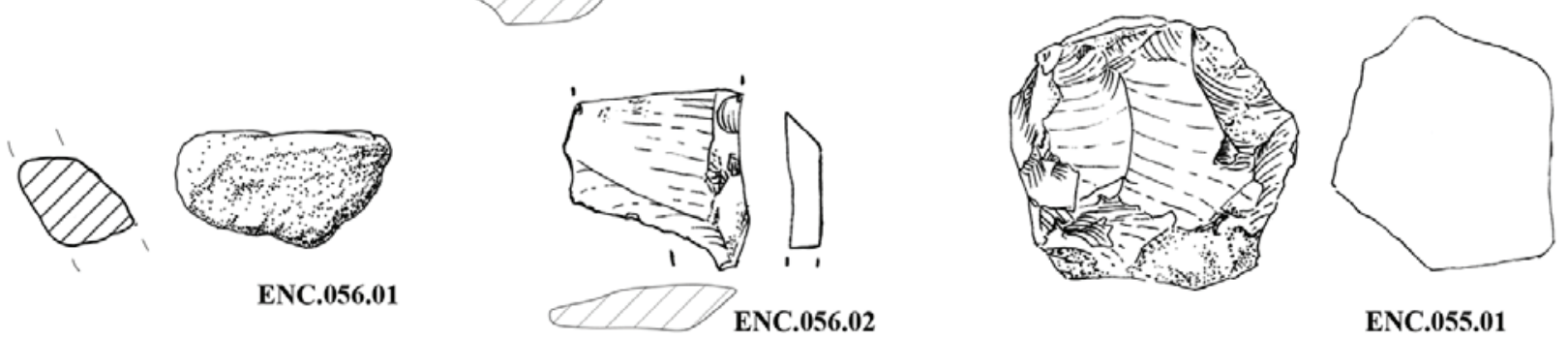

ENC.055.01

0 $5 \mathrm{~cm}$

Figura 9 - Materiais recolhidos nos sítios arqueológicos da Arieira (ENC.055), Valongo de Baixo (ENC.056), Ameixoeira (ENC.057 e Quinta dos Machados - Pincanceira 2 (ENC.059). Desenhos de Paula Bívar de Sousa. 



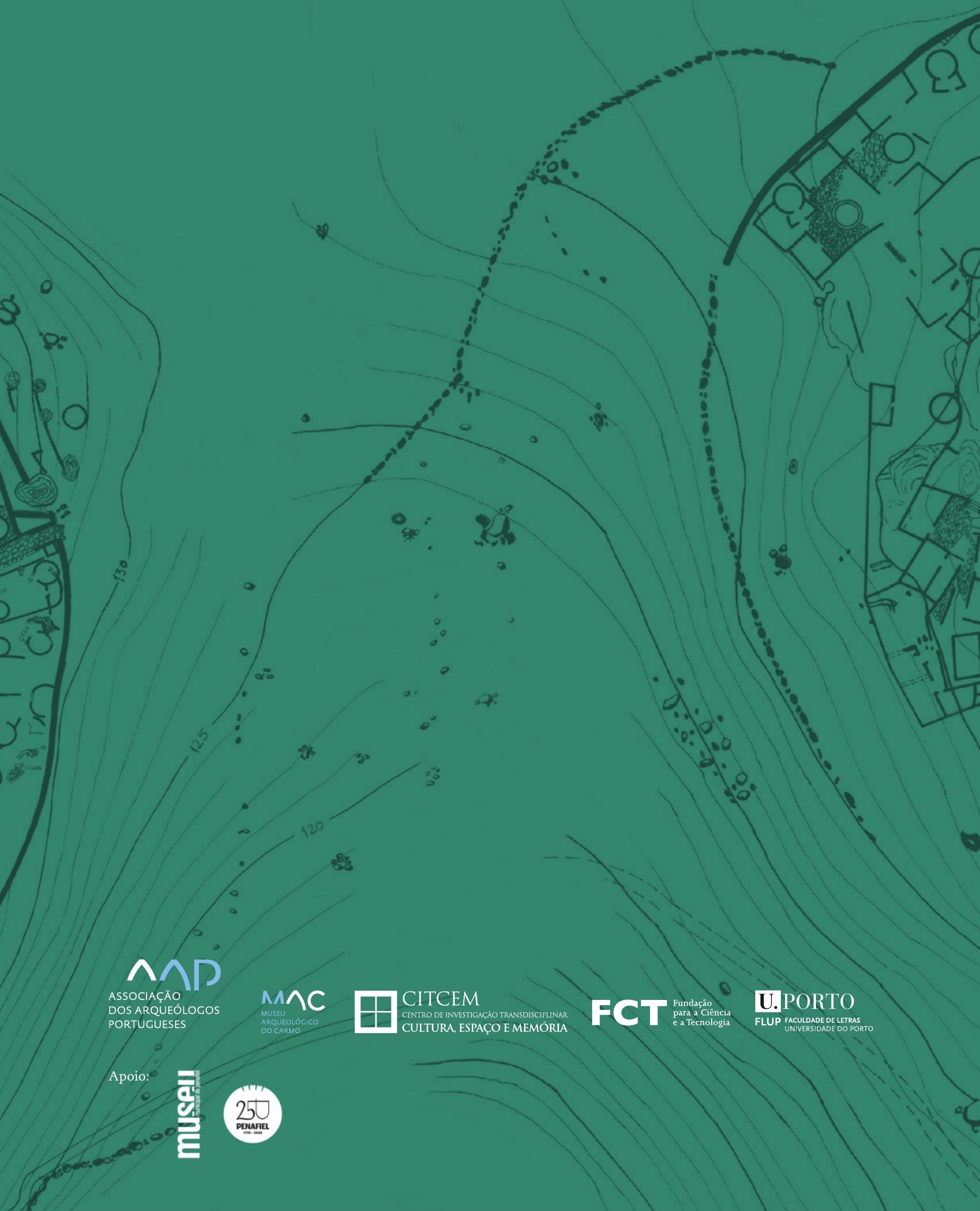

